\title{
Risk Tolerance, Self-Interest, and Social Preferences
}

\author{
Lucy F. Ackert* \\ Department of Economics and Finance \\ Michael J. Coles College of Business \\ Kennesaw State University \\ 1000 Chastain Road \\ Kennesaw, Georgia 30144 \\ (770) 423-6111 \\ lackert@kennesaw.edu \\ and \\ Research Department \\ Federal Reserve Bank of Atlanta \\ 1000 Peachtree Street NE \\ Atlanta, Georgia 30309-4470 \\ Ann B. Gillette \\ Kennesaw State University \\ (770) 499-3278 \\ agillet1@kennesaw.edu \\ and \\ Federal Reserve Bank of Atlanta
}

\author{
Jorge Martinez-Vazquez \\ Department of Economics \\ Andrew Young School of Policy Studies \\ Georgia State University \\ 14 Marietta Street \\ Atlanta, GA 30303 \\ (404) 413-0234 \\ jorgemartinez@gsu.edu
}

Mark Rider

Georgia State University

(404) 413-0227

mrider@gsu,edu

January 2009

* Corresponding author. The views expressed here are those of the authors and not necessarily those of the Federal Reserve Bank of Atlanta or the Federal Reserve System. Financial support of the International Studies Program at Georgia State University and the Federal Reserve Bank of Atlanta is gratefully acknowledged. The authors thank Vid Adrison for outstanding research assistance, and Glenn Harrison and participants of the ESA 2007 and APEE 2008 meetings for helpful comments. 


\title{
Risk Tolerance, Self-Interest, and Social Preferences
}

\begin{abstract}
We use an experimental method to investigate whether systematic relationships exist across distinct aspects of individual preferences: risk aversion in monetary outcomes, altruism in a twoperson context, and social preferences in a larger group context. Individual preferences across these three contexts are measured, and there is no possibility for risk sharing, wealth effects, or updating expectations of the population choices. We find that social preferences are related to demographic variables, including years of education, gender, and age. Perhaps most importantly, self allocation in a two-person dictator game is related to social preferences in a group context. Participants who are more generous in a dictator game are more likely to vote against their selfinterest in a group decision-making task which we interpret to be expressions of social preferences.
\end{abstract}

Keywords: Equity, social preferences, optimal taxation

JEL: C91, C92, D63, H21 


\section{Risk Tolerance, Self-Interest, and Social Preferences}

Preferences are central to economic decision-making. Economists generally assume that people's preferences can be adequately represented using models of homo economicus or economic man, a purely self-interested economic actor. However there is a growing body of evidence in economics, psychology, and sociology supporting the view that people are social beings (homo socialis) who are concerned with the well being of others as well as their own well being. In the economics literature such preferences are often referred to as social preferences. ${ }^{1}$ There are a number of theoretical models proposed in the literature that attempt to explain these findings. For example, Fehr and Schmidt (1999) and Bolton and Ockenfels (2000) assume social preferences are unconditional. In contrast, Rabin (1993), Cox, Freidman, and Gjerstad (2007), and Cox, Friedman, and Sadiraj (2008) model social preferences as conditional on the context of the specific game and the behavior of other players. Despite the progress in understanding and modeling social preferences, there is still much to be learned about them.

This paper reports the results of an experiment designed to shed further light on the nature of social preferences and provide useful insights to theorists attempting to model them. In our experiment, we first measure altruism, using a two-player dictator game, and then we measure social preferences in a group context. We use altruism and social preferences as convenient terminology to distinguish between behavior in a two person dictator game and behavior in a group context, respectively. This distinction in terminology is important because behavior in the group context need not be strictly altruistic; individuals may have malevolent motivates, such as spite or envy. Therefore, the behavior in the group context may not be altruistic, but nonetheless such behavior may be expressions of social preferences. In this paper we examine whether a person's expression of altruistic behavior in a dictator game is related to that same person's expression of social preferences in a group context. More specifically, we explore whether a person that is more (less) generous in a dictator game is more likely to act against (in favor of) their self-interest in a group task. Our approach also allows us to control for potential confounding effects, such as gender, age, income, and education.

\footnotetext{
${ }^{1}$ See, for example, Heinrich, Boyd, Bowles, Camerer, Fehr, and Gintis (2004).
} 
Since cooperation and benevolence may be adaptive responses for mitigating risk, it is interesting to examine whether there is any relationship between risk preferences and expressions of social preferences in a group task. ${ }^{2}$ Previous research also suggests that risk preferences may affect individual choices, therefore our experiment also includes a task in which we measure the risk preferences of participants. ${ }^{3}$ Finally, as discussed in greater detail below, Charness and Genicot (2004) and Charness and Gneezy (2007) report evidence that males take greater risks in investment games than females, and there is some evidence that women may be more generous or altruistic than men in dictator games. Therefore, it is important to control for gender in our regressions to eliminate this potential confounding variable.

Prior research suggests that there is significant variability among individuals in the three preference task measures we elicit. For example, Charness and Genicot (2004) report significant diversity in risk preferences among individuals. In contrast, Baker, Laury, and Williams (2007) and Harrison, Lau, Rutström, and Tarazona-Gómez (2005) report that risk preferences appear to be consistent with individually held risk preferences when individuals are placed in groups. Bolton, Katok, and Zwick (1998) report that some people are quite generous when matched with an anonymous partner in dictator experiments; whereas other people are purely self-interested. In addition, Ackert, Martinez-Vazquez, and Rider (2007) and Ackert, Gillette, Martinez-Vazquez, and Rider (2007) find that while many people are unwilling to sacrifice their own income to benefit another in experiments that measure social preferences, some are willing to forfeit income to benefit others. In this paper we combine the three tasks described above to investigate whether risk preferences as expressed in an investment game, altruism in a dictator game, and social preferences in a group voting task with status are independent of each other and

\footnotetext{
${ }^{2}$ For example, Collier and Gunning (1999) in their fascinating article on Africa's growth performance explains that traditional African societies evolved the institutions of village and kinship group to reduce consumption risk due to weather related shocks to agriculture while reducing the potential costs of moral hazard and adverse selection. As they explain, membership in the kinship group is based on birth, which is nonelective, thus solving the problem of adverse selection. Living in close proximity to one another reduces monitoring costs thus solving the problem of moral hazard. Another example of cooperation among members of a species to reduce environmental risks is herding behavior among cattle or schooling among some species of fish. This behavior is believed to be an adaptive response to a hostile environment that requires cooperation among members of a species to mitigate the risks of predation.

${ }^{3}$ See, for example, Charness and Genicot (2004), Charness and Gneezy (2007), and Charness and Villeval (2007).
} 
independent of observable attributes of the decision-maker, such as gender, age, and so on. Importantly we use a within-subject design to account for heterogeneity of individual preferences while controlling for possible confounding effects of risk sharing, changes in population expectations, and wealth effects.

The remainder of this paper is organized as follows. In section I we describe the experiment, including the details of each of the three tasks. In section II we present the findings for each of the individual tasks. In section III we consider whether a person's risk preferences and expression of altruism in a two-person dictator game can predict her expressions of social preferences in a group context. We conclude in section IV with a summary of our results and suggestions for future research.

\section{Experimental Design and Method}

Each experimental session includes three tasks to measure distinct aspects of individual preferences: risk preferences, altruism, and social preferences in a voting game. We conducted a total of six sessions, and every subject completed all three sections of the experiment. There are two subject pools. Four sessions included students at a large urban university (students), and two sessions included foreign nationals who work in the area of public policy (policy group) in developing countries. Salient monetary earnings were paid with average earnings of about $\$ 50$ per participant. The instructions are included in appendix A, and table 1 summarizes the experimental sessions.

At the beginning of each session, participants were randomly seated and widely dispersed in a large classroom to maintain privacy in decision making. Introductory written instructions were distributed, and the experimenter (the same person in all six sessions) read the instructions aloud as participants followed along. Instructions for each of the three tasks were distributed after each preceding section was completed. Participants were told that there would be three sections to the experiment and that their choices in one section would not affect their choices or earnings in any other section. To reduce the potential for wealth effects across sections, outcomes and earnings for each section were determined at the end of each session.

The first section of the experiment provides a measure of risk aversion regarding monetary outcomes. Participants were asked to allocate ten dollars between a safe and risky asset. The second section measures a participant's social preferences in a two-person context, using 
their responses as an allocator of ten dollars in an anonymous dictator game. The third section measures a participant's social preferences in a group context by asking them to choose between two tax distributions. Each of the thirteen pairs of tax distribution choices involved an anonymous group of five members where each group member has a unique and pre-determined pre-tax income level. A subject's endowed pre-tax income level in this task reflects his status, or relative position, in the group.

At the end of each session earnings for each section of the experiment were determined and total earnings calculated. In addition to their earnings from the three tasks, subjects earned $\$ 4$ if they arrived on time to the experiment and \$4 for completing a post-experiment questionnaire which was designed to gather demographic information as well as their views on the experiment. The specific design considerations for each section of the experiment are described below in greater detail.

\section{Section 1: Risk Preferences}

After a general introductory section was read to the participants, instructions for the investment task were distributed. The purpose of this first task is to elicit individual risk preferences. Participants were asked to make a single choice regarding the investment of cash. They were given an endowment of $\$ 10$ of which they could invest any portion in a risky asset that had a 50 percent chance of success. To determine earnings from the investment, a randomly chosen participant flipped a coin at the end of the experimental session to determine the success

of the investment. ${ }^{4}$ If the investment was successful, the amount invested increased in value by 2.5 (or 250 percent), and if it was unsuccessful each participant would lose the amount that they invested in the risky asset. Thus, a participant's section 1 earnings was the sum of the portion of the $\$ 10$ that they did not invest plus the amount that they did invest times zero or 2.5 , depending on the outcome of the coin flip. After participants completed both decision sheets, the "Investment Choice Sheets" were collected by a monitor so that participants could not change their investment decision, and the participants put "Their Copy" into their folder of experimental materials.

Section 2: Altruism

\footnotetext{
${ }^{4}$ The results of the coin tosses are reported in table 1.
} 
As in section 1, participants were asked to make a single choice concerning the allocation of $\$ 10$ in cash, but this time the allocation was between themselves and another anonymous, randomly selected participant in the session. They were told that at the end of the experimental session 50 percent of the participants would be randomly chosen to be allocators. Allocators would earn the amount they allocated to themselves, while the remaining participants would be recipients whose earnings would be determined by the "recipient amount" allocated by one of the chosen allocators. Participants were told that in making their allocation choice they should assume that they would be among the chosen allocators. The purpose of this second task was to elicit altruistic or benevolent behavior in a two-person context.

The instructions make it clear that neither they, nor their matched partner, would be able to discover one another's identities at any time. To maintain the anonymity of the matched partner, participants were given a code ID at the top of the first two pages of their section 2 instructions. This code ID was completely different from their participant number, which was used for decisions in the experimental session. Neither the code ID nor the participant number appeared on the third sheet or "Recipient Copy" of section 2. This ensured the allocator's anonymity to the matched recipient partner. Participants were instructed that their allocation decision must be the same on all three sheets. After making their allocation choices, participants were asked to put their sheet labeled, "Instructions for Section 2," in their folders and then fold the other two sheets together, labeled "Allocator (or Recipient) Copy," so that a monitor could collect them. By having these two sheets folded together, the monitor could later identify and select the chosen allocator's "Recipient Copy" to hand out to the randomly chosen recipient.

The anonymous randomization of the participants as allocators or recipients was executed in the following way. When the section 2 instructions were handed out, each participant was given a poker chip that had the same code ID number on it as on their instruction sheet. Participants were asked to verify that the code ID was the same and to place the chip into the monitor's empty bucket. In a session of twenty (ten) participants, ten (five) chips were randomly drawn from the bucket at the end of the session. The selected chips identified the participants, by code ID, who became the designated "allocators."

\section{Section 3: Social Preferences}

After making their two-person allocation choice, the instructions for section 3 were read aloud. After the section 3 instructions were completed and all participant questions were 
answered, the thirteen tax decision choice sheets were distributed. Each decision is a paired choice between "Tax 1" and "Tax 2" which determined the tax, and consequently after-tax income and section earnings, for each member of a five person group. The vote of the majority of each group determined the tax for that group. The purpose of this third task was to elicit individual social preferences in a group context.

There were twenty (ten) participants in each session and thus four (two) different groups per decision. The members of the groups for each of the thirteen decisions were anonymous and pre-randomized, and each member within a group had a different pre-tax income level. In all thirteen decision pairs, Tax 1 is always a flat $\$ 5$ tax for each member of the group. The paired Tax 2 distributions were chosen, given the limits of our time and attention, to minimize collinearity so that we could evaluate as many theories of social preferences as possible. Participants knew that only one of the thirteen decisions would be randomly chosen for the determination earnings for this section. ${ }^{5}$

The pre-tax income or status of each participant was determined by drawing a card from a set of twenty (ten) cards, one for each participant. In the set of cards there were four (two) cards for each of the five pre-tax income levels: \$10, \$20, \$30, \$40, and \$50. Participants were told to keep their income card private information and that they would have the same pre-tax income for all thirteen decisions. As the cards were drawn, a monitor recorded the pre-tax income level by participant number which facilitated the pre-randomization of groups. Participants were informed that the groups were randomized so that there was always one member with each of the five pre-tax income levels. To set a common knowledge benchmark, they were also told that the total income in each group was $\$ 150$, and the average income was $\$ 30$. Both the after-tax income distribution and taxes paid by each group member were presented in table form next to the pre-tax income levels for each tax distribution choice. Although one piece of information can be easily calculated from the other, we presented both pieces of information to eliminate possible framing biases across individuals. Participants had 30 minutes to complete the thirteen decisions, and this was never a binding constraint. After all decision

\footnotetext{
${ }^{5}$ Recently, Hey and Lee (2007) examine whether when paying subjects for just one choice they respond to the complete set of questions or separate various questions. They conclude that subjects separate the various questions.
} 
sheets had been collected a monitor tallied the votes by decision for each group which was shown on a screen using an overhead projector during the earnings determination section.

The design considerations of group anonymity and the reporting of majority votes after all decisions reduces the possibility of visually-related personal biases, controls for wealth effects between decisions, and promotes stationarity of population expectations across the thirteen decisions. Importantly, there is no economic incentive for risk sharing in this task because (1) income level and income rank for each participant were held constant, (2) group membership was anonymous, and (3) groups were re-randomized after each of the thirteen tax distribution decisions.

\section{Experimental Results}

A total of 110 subjects completed the experiment, including 70 university students and 40 foreign nationals in the policy group. Three participants did not provide their age, so we eliminated them from the sample used for analysis. Descriptive statistics for the sample of 107 participants and for each subject pool are reported in table 2. The average age across both subject pools is 31.6, with the average age of the policy group somewhat greater (41.4) than the university students (26.2). Thirty-six percent of our sample reported household income greater than $\$ 25,000$ per year, and the corresponding figure for the policy professionals is only 18 percent. These features of our sample reflect the fact that a large fraction of the student population consists of part-time students many of whom work full-time, and the policy professionals come from very low income countries, primarily in Sub-Saharan Africa. Across all participants, 65 percent are male, 65 percent self-supporting, and 21 percent report household incomes in excess of $\$ 50,000$ per year.

\section{Section 1: Risk Preferences}

As previously discussed, each participant was asked to allocate $\$ 10$ between a risk free asset and a risky one. Figure 1 illustrates the frequency of allocations to the risky asset for the complete sample of 110 participants. On average, participants allocated $\$ 6.12$ to the risky asset. Every participant allocated something to the risky asset and most risked at least half of their endowment. Over forty percent of the participants invested between $\$ 4$ and $\$ 6$, with the modal frequency at half the endowment (\$5). Only 2.7 percent of participants invested $\$ 2$ or less in the risky asset, while approximately 15 percent invested at least $\$ 8$. This distribution of risk 
preferences across investment categories is similar to that reported by Charness and Genicot (2004). In the empirical analysis presented below we denote the amount invested in the risky asset as "risky," which is our measure of individual risk preferences. As previously noted, a higher value of "risky" indicates a greater tolerance for risk taking.

To examine whether individual attributes are related to risk preferences in this task, we estimate OLS regressions where the dependent variable is the amount allocated to the risky asset. The independent variables include the number of years in university (years in university); a dummy variable set equal to 1.0 if female (gender); a dummy variable set equal to 1.0 if the participant is a member of the policy group (policy students); number of completed university courses in finance and economics (economics courses); a dummy variable set equal to 1.0 for business majors (business students); a vector of dummy variables indicating whether the participant's primary source of income is self-support (self support), support by a parent (parental support), or support by a spouse (spousal support); total household income; and age and age-squared. ${ }^{6}$ All of this information was self-reported by the participants on the post-experiment questionnaire.

The regression results are reported in table 3. We report the results of a variety of specifications in order to shed light on the stability of the estimated coefficients to the inclusion of the demographic variables. However, our discussion of the results focuses on the estimates reported in the last column of table 3. They indicate that males and subjects in the policy group are less risk averse. In addition, those whose primary source of income is through self-support or parental support are less risk averse. According to our estimates, risk is nonlinear in age. Risk aversion is increasing at a decreasing rate in age and reaches a maximum at the age of 82 which is outside the range of our data.

The significance of gender in risk-taking behavior is consistent with the evidence reported in the existing literature. Charness and Genicot (2004) and Charness and Gneezy (2007)

\footnotetext{
${ }^{6}$ Total household income is a variable that assumes integer values between 1 and 5, where 1.0 indicates total household income is less than $\$ 25,000 ; 2.0$ indicates household income is between $\$ 25,000$ and $\$ 50,000 ; 3.0$ indicates total household income is between $\$ 50,000$ and $\$ 75,000 ; 4.0$ indicates total household income is between $\$ 75,000$ and $\$ 100,000$; and 5.0 indicates total household income is greater than $\$ 100,000$.
} 
also report that males invest more in the risky asset. ${ }^{7}$ Increased risk-taking by men may be related to their tendency toward overconfidence which can lead to sub-optimal decision-making. For example, based on 35,000 household brokerage accounts Barber and Odean (2001) present evidence that men trade more often than women, and men also generate lower returns to trades.

In contrast to our findings, Charness and Villeval (2007) find that their older participants are not more risk-averse in their experiments. Similarly, Ackert, Church, and Englis (2002) report evidence that age does not affect people's portfolio allocations to equity. Importantly they find that psychological orientation, regardless of age, affects the way investors make risky choices. In the tax compliance literature, however, age is often included as an explanatory variable in tax compliance regressions. Typically such studies report that tax compliance increases with the age of the taxpayer; in other words, older taxpayers, ceteris paribus, are more compliant in paying their tax liabilities than younger taxpayers. ${ }^{8}$ This finding is typically interpreted to mean that older people have a lower tolerance for risk.

\section{Section 2: Altruism}

As previously discussed, participants also were asked to make a single choice concerning the allocation of $\$ 10$ in cash between themselves and another anonymous, randomly selected participant in the session. Randomly chosen allocators received the amount they allocated to themselves, while the remaining participants received the amount allocated to the recipient by their randomly paired allocator. As figure 2 shows for the complete sample of 110 participants, the vast majority kept at least half of their endowment of \$10. On average, participants' selfallocation is $\$ 6.90$, denoted in subsequent analysis as “self". In fact, 18 percent of the participants kept all of it. By comparison, 36 percent of the participants in Forsythe, Horowitz, Savin, and Selton (1994) offered zero to their paired recipient in a dictator game. ${ }^{9}$

\footnotetext{
${ }^{7}$ In their survey of the literature, Croson and Gneezy (2004) report that the majority of laboratory and field studies conclude that women are more risk-averse.

${ }^{8}$ See, for example, Clotfelter (1983), Joulfaian and Rider (1996 and 1998), and MartinezVazquez and Rider (2005).

${ }^{9}$ Many dictator games are reported in the literature and there is significant variability in selfallocations. In their examination of this variability, Bolton, Katok, and Zwick (1998) conclude that differences in context and written instructions are the sources of the observed inconsistencies. Our instructions, included in the appendix, are standard and because earnings from all sections are determined at the end of the experiment, the total earnings available across the experiment should not impact allocations in the dictator game.
} 
To examine whether individual attributes are related to self-allocations, we estimate regressions with the dependent variable defined as the allocation to self. The independent variables are the same as those used in the regressions for the allocation to the risky asset. The results reported in table 4 indicate that self-allocation is positively correlated with the number of economics and finance courses, and negatively correlated with self- and spousal-support. We report the results of a variety of specifications in order to shed light on the stability of the estimated coefficients to the inclusion of the demographic variables. However, our discussion of the results focuses on the estimates reported in the last column of table 4 . The statistical significance of the variable "number of economics and finance courses" in our anonymous dictator context is consistent with the finding by Frank, Gilovich and Regan (1993) that there is a training effect in economics in certain cooperative contexts; although the extent differs across games, communication protocols, and anonymity conditions. Turning back to the discussion of the results reported in table 4, participants who support themselves or are supported by a spouse actually are more generous, keeping less of their allocation for themselves, than those who are supported by their parents or receive other means of support, such as scholarships. It is noteworthy that gender, subject pool, age, and age-squared are not statistically significant at conventional levels. ${ }^{10}$

Previous research reports inconsistent findings regarding the relationship between gender and altruism. Social science research concludes that females are more pro-socially oriented than males, and in their baseline dictator experiments Eckel and Grossman (1998) find that women are twice as generous as men. However, Cox and Deck (2006) conclude that the question of which gender is more generous does not have a simple answer. They contend that the context of the decision is critical. For example, women are more likely to be generous when the stakes are

\footnotetext{
${ }^{10}$ We also estimated specifications that included the variable "risky", but the estimated coefficient is statistically insignificant at conventional levels, so these results are not reported here. Since there is no opportunity for reciprocity in a dictator game, it perhaps comes as no surprise that attitudes toward risk do not appear to play a role in the amount allocated to self. However, we thought that if cooperative behavior is an evolutionary response to mitigate environmental risks such as predation, then perhaps we would find a relationship between a person's attitudes toward risk and altruism in a dictator game. In other words, if these preferences are somehow hard-wired in our species, and one in response to another, then perhaps the two preferences covary in an individual, and this correlation would potentially manifest itself in the two games. In any event, our results do not support this hypothesis.
} 
smaller. Croson and Gneezy (2004) conclude that women are typically more generous than men when efficiency is not a concern. If efficiency gains are possible, women choose equal payments whereas men tend to choose the more equal allocation. As for the insignificant effect of age on social preferences, no previous study of which we are aware reports a significant effect of age, with the exceptions of Murnighan and Saxon (1998) and Fehr, Bernhard, and Rockenbach (2008) who report that very young children are more generous.

\section{Section 3: Social Preferences}

Our third task provides a measure of participants' social preferences in a group context allowing for potential status effects, as induced by the endowed pre-tax income levels. In our participant pool we find that slightly more than 80 percent of observed votes are consistent with self-interest, i.e., voting for the distribution that maximizes own payoff. Interestingly, only 48 percent of the participants consistently vote for the distribution that maximizes own payoff across all 13 tables. Of the 1,391 votes cast in the third task of our experiment, 246 votes are consistent with a willingness to sacrifice. In our analysis, we classify a decision as consistent with self-interest (social $=0$ ) if the vote is cast for the distribution that maximizes own payoff; whereas a vote is consistent with social preferences $($ social $=1)$ if the subject votes for the alternative with a smaller own payoff. Seventeen percent of the votes reflect motives that are not consistent with maximizing own payoff, and 52 percent of the individuals vote at least once against maximizing their own payoff. As reported in Ackert, Gillette, Martinez-Vazquez, and Rider (2007), this result is consistent with Charness and Rabin (2002) among others who report evidence of social preferences in individual and group decision making contexts. ${ }^{11}$

Figure 3 illustrates the distribution of the 246 other-regarding votes, according to the cost or sacrifice from voting against the alternative that would maximize own payoff. The horizontal axis indicates the sacrifice in terms of loss in own payoff from voting against one's own-interest. The vertical axis is the percent of other regarding votes in which the numerator is the frequency

${ }^{11}$ Ackert, Gillette, Martinez-Vazquez, and Rider (2007) use the data from the third task of the experiment reported in this paper to examine the mini-max preferences of Rawls (1971) and the inequality aversion model of Fehr and Schmidt (1999). They conclude that both models help explain the choices of participants. In contrast, in a highly influential study, Engelmann and Strobel (2004 and 2006) find inequality aversion has no additional explanatory power relative to a model that simply accounts for mini-max preferences and concerns about efficiency or the sum of all payoffs. 
of social votes for a given sacrifice in own-payoff, and the denominator is the number of the 1,391 total votes that could potential result in a given sacrifice. In this manner, figure 3 controls for the number of opportunities out of 1,391 opportunities to cast a social vote for each given sacrifice. It is interesting to note that the percent of social votes is decreasing in the size of the sacrifice in own-payoff, suggesting an inverse relationship between social preferences and the price of expressing such preferences. Turning to figure 4, it shows the distribution of social votes by status level for the complete sample of 110 participants. As the figure indicates, we actually observe more social votes for high status participants (income $=\$ 40$ and $\$ 50$ ) than for those whose status is below the median (income $=\$ 10$ and $\$ 20$ ). Interestingly the results from the third task do not appear to support a strong role for status in determining social behavior. More specifically there are 77 social votes among the low status participants as opposed to 98 social votes among the high status participants. At first glance status in this task does not appear to determine generosity. However, as we show below, status has a positive and statistically significant effect at conventional levels on the probability of casting a social vote.

\section{Do Risk Preference and Selfishness Predict Social Preference?}

To examine whether an individual's risk preferences in monetary outcomes, altruism in a two-person context, and social preferences in a group context are systematically related, we next combine the evidence collected across the three tasks described above. Can we predict whether an individual expresses social preferences based on decisions observed regarding risk preferences and altruism defined in a two-person context?

The challenge in selecting an econometric model for gauging the determinants of social preferences or tastes for distributional equity is twofold. First, there is not a widely accepted economic theory of the way in which social preferences enter the individual utility functions. There are a number of competing theories, and the research on the relative performance of these theories is in its infancy. Second, the source of social preferences is not clear. According to one school of thought, other-regarding behavior is an intrinsic attribute of the individual that may be independent of the observable characteristics of the individual, such as age, gender, education, income, and so on. In contrast, others contend that fairness and altruism result from biology, socialization, and other life experiences. For still other researchers, social preferences depend on the behavior of others and an individual's status, so that other-regarding tendencies vary for a 
particular person across situations. To further complicate matters, there is some preliminary evidence that a large fraction of the population may be conditional cooperators, while others may be unconditionally cooperative (Mother Theresa being perhaps an example), and still others may be unconditionally competitive as assumed in the conventional model of economic man.

One must first choose among the competing theories of social preferences in order to choose an appropriate econometric model. Rather than taking a firm stand among these competing theories, we adopt the strategy of trying to model each theory and gauge the performance of the different models. More specifically, we estimate probit regressions with a binary dependent variable which indicates whether the participant votes for or against selfinterest in the social preferences task (social vote $=1$ ). The independent variables include individual's risk preferences, status, self-allocation in the dictator game, sacrifice in own-payoff from voting against one's self interest, the changes in disadvantageous and advantageous inequality, and the demographic variables used in the previous analyses of the other two tasks. ${ }^{12}$

In the inequality aversion model of Fehr and Schmidt (1999) people are concerned about their own payoff but are averse to disadvantageous and advantageous payoff inequality. Following their definitions, we measure the difference in disadvantageous and advantageous inequality in the social preferences task using $\Delta(\mathrm{n}-1)^{-1} \Sigma_{\mathrm{j}} \max \left(\pi_{\mathrm{j}}-\pi_{\mathrm{i}}, 0\right)$ and $\Delta(\mathrm{n}-1)^{-1} \Sigma_{\mathrm{j}} \max \left(\pi_{\mathrm{i}}-\pi_{\mathrm{j}}\right.$, 0 ), respectively, where $\pi_{\mathrm{i}}$ is the payoff of the $\mathrm{i}^{\text {th }}$ participant. ${ }^{13}$ Again, we report the results of a variety of specifications in order to shed light on the stability of the estimated coefficients on the

${ }^{12}$ Ackert, Gillette, Martinez-Vazquez, and Rider (2007) include a measure of change in the payoff to the worst off participant to control for mini-max preferences and the change in the sum of individual payoffs to control for concerns about efficiency. When these variables are included in the analysis of this paper these variables do not explain participant choices. We believe that this discrepancy in findings in two closely related studies stems primarily from the differences in the definition of the dependent variable. The dependent variable as we define it here provides a more restrictive test of social preferences because it attempts to explain votes for or against one's own self-interest. Whereas, in Ackert et al. (2007) the dependent variable is simply coded 1 if the participant votes for tax 2 and 0 otherwise. The sensitivity of the results seemingly to minor changes in model specification highlights the complexity of using a generic term such as altruism to explain multifaceted social behavior within and across games.

${ }^{13}$ Note that in this study, we calculate the difference in disadvantageous inequality (ddi) and the difference in advantageous inequality (dai) differently than in Ackert et al (2007). In this study, ddi and dai are calculated relative to the tax ( 1 or 2$)$ that reduces the individual's own payoff; whereas, Ackert et al. calculate ddi and dai relative to tax 2. The calculation of ddi and dai is different because of the change in the definition of the dependent variable described above. 
variables of primary interest to the inclusion of the demographic variables. However, our discussion of the results focuses on the estimates reported in the last column of table 5.

The results reported in table 5 indicate that those participants with changes in advantageous inequality, higher number of years in university, who are males, business students, and higher income, are less prone to cast social votes. In contrast, higher status participants and those whose primary source of financial support is self-support are more likely to cast social votes. Risk preferences do not appear to play a significant role. Perhaps of greatest interest in the present context is that the estimated coefficient of the variable "self allocation in dictator game" is negative and statistically significant at conventional levels. This finding is consistent across all five specifications, and so this result is unlikely due to omitted variables or confounding effects. The finding suggests that individuals that allocate more to the recipient in the dictator game are more likely to vote against their self interest in the group context. In other words, the behaviors in the two games appear to be related to one another. ${ }^{14}$

We also believe that our results confront us with a paradox. The motive in the group context that would be most obviously consistent with altruistic preferences is aversion to disadvantageous inequality. Yet, the estimated coefficient on the variable used to control for this preference is statically insignificant at conventional levels. As previously noted, we also estimate specifications that control for mini-max preferences and concerns about efficiency which would also be consistent with altruistic preferences. However, the estimated coefficients of these control variables are also statistically insignificant at conventional levels. While we find a role for altruism in explaining the votes against one's own self interest, the variables that we use to control for such preferences are statistically insignificant. In contrast, we find that aversion to

\footnotetext{
${ }^{14}$ We also estimated specifications that include the variable "risky" which is the individual's allocation to the risky asset and a proxy measure of that individual's attitude toward risk. The estimated coefficient of this variable is statistically insignificant at conventional levels. As previously noted the design of this section carefully excludes any opportunities for risk sharing; therefore, it perhaps comes as no surprise that attitudes toward risk do not appear to have any predictive ability in the context of this game. As previously discussed, however, we thought that perhaps, if our species is hard-wired to cooperate as a means originally of mitigating environmental risks, such as predation, then risk aversion and altruism may be correlated with one another in our hard-wiring, and this feature of the make-up of our species would potentially manifest itself in our experiments. The results of the experiments reported here lead us to reject this hypothesis.
} 
advantageous inequality helps explain votes against one's own self interest. Yet, this motive would seem to reflect envy or spite, not altruism.

On the one hand, the findings reported in this paper should be reassuring to theorists and behavioral economists alike because there is some consistency in motives across the two games examined in this study. Specifically, our results suggest that the willingness to sacrifice own payoff to benefit another in the two person dictator game is related to the willingness to sacrifice own payoff in the group context to benefit others. On the other hand, our results raise concerns because they suggest that we do not have a satisfactory theory of altruistically motivated behavior in a group context.

Finally, the results of an alternative estimated model provide additional insight. Since the focus of this paper is to explain the behavior of those who sacrifice their own payoff to benefit others, we are particularly interested in the sub-set of individuals among the 107 participants in our experiment who voted at least once against maximizing their own payoff in the 13 tax decisions. However, we can not simply estimate models on this subset of participants because this would raise the issue of sample selection bias. To address this concern, we estimated a Heckman type sample selection model. Using our sample of 107 participants, we estimated a first stage regression in which the dependent variable is a binary variable equal to 1.0 if the participant voted at least once against maximizing their own payoff in the 13 tax decisions, and 0 otherwise. We use "self allocation in the dictator game" as an instrumental variable in this first stage regression which also includes the other regressors employed in table 5. Self allocation has the expected positive sign and is statistically significant at conventional levels. Then, we compute the inverse Mills ratio and include it in a second stage regression in which the dependent variable is defined as in table 5, or equal to 1.0 if the vote cast is for the tax that reduces one's own payoff. This second stage regressions includes all the regressors used in table 5 , except self-allocation which is excluded in the second stage regression in order to identify the parameters of the model. In contrast to table 5, this second stage regression is estimated using only the votes cast on the 13 decisions by the subset of participants who cast a vote against their self interest at least once. Interestingly, we reject the hypothesis at conventional significance levels that the two equations are statistically independent, using a likelihood ratio test. The pvalue of this test statistic is 0.26 , which indicates that this model has some merit. In any event, the results of the second stage regression are generally consistent with the estimates reported in 
table 5; therefore, in the interests of space, we do not report these results. However, these results are suggestive and may be worth pursuing in future research.

\section{Summary}

We examine risk preferences, altruism, and social preferences in a laboratory experiment where we specifically control for risk sharing, changes in population expectations, and wealth effects. We report a systematic relationship between self allocation in a dictator game and social preferences in a group task, suggesting that social preferences, or the lack thereof, may be a fundamental trait of each individual's psychological orientation that explains behavior in the two contexts. Importantly social behavior can be predicted by years of education, gender, university major, age, and primary household support. Participants who are less educated, female, nonbusiness majors, older, and not primarily supported by their spouse are more likely to vote against their self-interest. Risk preferences are related to gender, but do not appear to be systematically related to age or altruistic behavior. Among participants who vote socially, those with higher relative status in our experiment actually voted more often against their self-interest, compared to those with lower status.

Future research should examine the impact of earned status on social behavior. Recall that status is endowed in our experiment. The existing literature does not provide a clear answer to the question of whether an earnings-based notion of justice has important effects on social preferences (see, for example, Rutström and Williams 2000 and Hoffman and Spitzer 1985). Another important issue for future investigation is how reciprocal behavior impacts a person who is a conditional cooperator. How do past actions and expectations of future actions of those with whom we interact affect our future behavior? Surely a person's choices are not independent of others but how quickly does behavior adapt and when does the change become permanent, if ever? The goal should be a parsimonious model of behavior. In our ancestral past, mammals, primates, or people, depending on the stage of evolution, engaged in repeated interactions that many believe may have hard-wired us to react in certain ways. An important question regarding the source or relative weighting of social preferences remains: nature or nurture? 
Appendix A

\section{Instructions}

The experimental instructions for each section of the experiment follow.

\section{General Instructions}

This experiment is concerned with the economics of decision-making. There are three instructional decision-making sections. After one section is completed, we will move to the following section. Your total earnings will be the sum of your individual section earnings and will be paid to you in cash at the end of the session today. Note that your choices in a given section will not affect your choices or earning potential in any other section.

It is important that you do not talk or make noises during the experiment. All of your decisions in the experiment are your own private information. If you have any questions at any time, please raise your hand and a monitor will come to assist you.

[New page]

\section{Instructions for Section 1 "Your Copy"}

\section{Participant ID}

You are asked to make a single choice. The choice concerns the investment of cash. You are endowed with $\$ 10$ and can invest any portion of the $\$ 10$ in a risky asset that has a 50\% chance of success. If the investment is successful, the amount invested increases in value by 2.5 (or $250 \%$ ). The amount you do not invest does not change in value and is yours to keep. Note that if you invest $\$ \mathrm{Z}$ in the asset there are two equally likely outcomes:

1. $\$ 2.5 * Z+\$(10-Z)$ or, in words, you invest $\$ Z$ and the investment is successful.

2. $\$(10-Z)$ or, in words, you invest $\$ Z$ and the investment is unsuccessful.

At the conclusion of the experiment today, we will actually determine the outcome of your investment choice. A participant in this room will toss a coin and if heads appears, the investment is successful and the amount you invested grows by $250 \%$. If tails appears, you lose the amount you invested and take home $\$(10-Z)$.

After all participants' questions have been answered, please indicate your investment below. Then record this amount onto the "Section 1 Investment Choice Sheet" which a monitor will pick up from you and verify that you have recorded the same investment choice on both sheets. After the monitor has been by, please put this sheet into your folder until the end of the experiment when earnings will be determined. You will have 5 minutes to record your investment.

I invest \$ in the risky asset. Remember that you can invest any amount from $\$ 0$ to $\$ 10$. 


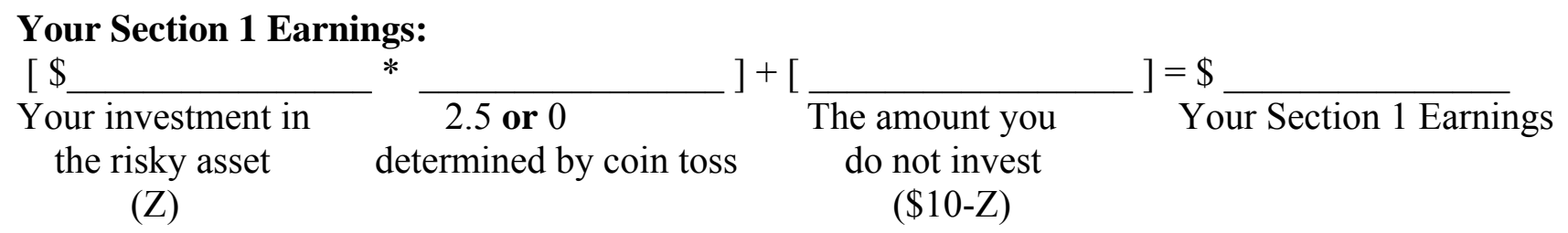

Recall that after all sections of the experiment are completed a coin will be tossed to determine the success or not of your investment. At that time you will calculate your earnings for this section.

[New page]

\section{Participant ID}

\section{Section 1 Investment Choice Sheet}

I invest \$ in the risky asset. Remember that you can invest any amount from $\$ 0$ to $\$ 10$ and this must be the same amount that you recorded on the Instructions for Section 1 sheet labeled, "Your Copy".

[New page]

\section{Code ID}

\section{Instructions for Section 2}

You are asked to make a single choice. Recall that, your choice in a given section does $\underline{n o t}$ affect your choices or earning potential in any other section. The choice concerns the allocation of $\$ 10$ in cash to yourself (the allocator) and another anonymous, randomly selected participant (the recipient) in this room. Neither of you will be told at any time or be able to find out the identity of your matched partner.

Notice that there are three sheets in this section of the instructions. The first two sheets have a code ID instead of your participant number, and the third sheet, the "Recipient" Copy for Section 2, has neither a code ID nor a participant number. This is to ensure the anonymity of your decision to the other participants in the room. Your allocation decision must be the same on all three sheets. After you have recorded your allocation choice on all three sheets, please put this sheet (labeled Instructions for Section 2) in your folder and then fold together the other two sheets, labeled respectively, Allocator (Recipient) Copy for Section 2, and place them face down on your desk. A monitor will then come by and collect these two sheets.

In responding you should assume that you will be among the allocators. Suppose as an allocator you choose to allocate $\$ \mathrm{X}$ to yourself and $\$(10-\mathrm{X})$ to a recipient. If you are among the $50 \%$ of participants selected as an allocator, you will receive $\$ \mathrm{X}$ and a randomly chosen participant will receive $\$(10-X)$. 
At the conclusion of the experimental session today, half of the participants in this room will be randomly selected to take the role of the allocator. The other half of the participants will be recipients. With these instructions you received a poker chip marked with your code ID number. A monitor will now come by and collect them into an empty bucket. At the end of session, ten chips will be randomly drawn from the bucket. These selected chips will identify the participants, by code ID, who will be the designated "allocators" for this section of the experiment. Those participants whose code ID chips were not selected will be the designated "recipients". For the chosen allocators, their respective "Recipient" Copy of Section 2 sheets will then be randomized and handed out to the designated recipients. Thus, if your code ID chip is selected your earnings will be the allocation of the $\$ 10$ that you gave yourself. If your code ID chip is not selected, your earnings will be determined by the recipient allocation on the sheet randomly handed to you.

After all participants' questions have been answered, please indicate your allocations below. You will have 5 minutes to record your decision.

I allocate $\$ \_$to myself and the recipient gets $\$$ ___ Remember that you can allocate any amount from $\$ 0$ to $\$ 10$ but the allocation to yourself and the recipient must sum to $\mathbf{\$ 1 0}$. Please put this sheet in your folder when you are finished making your allocation decision.

[New page]

\section{Code ID}

\section{“Allocator” Copy for Section 2}

I allocate \$ to myself and the recipient gets $\$$

Remember that your allocation must be the same on all three sheets. Recall that you can allocate any amount from $\$ 0$ to $\$ 10$ but the allocation to yourself and the recipient must sum to $\$ 10$.

[New page]

\section{Recipient” Copy for Section 2}

I allocate \$ to myself and the recipient gets $\$$

Remember that your allocation must be the same on all three sheets. Recall that you can allocate any amount from $\$ 0$ to $\$ 10$ but the allocation to yourself and the recipient must sum to $\$ 10$.

[New page] 


\section{Instruction Section 3}

This section of the experiment consists of a series of thirteen decisions. You will not find out how much you have earned until you have completed all thirteen decisions. You will be given a maximum of 30 minutes to complete this section of the experiment.

For each of the thirteen decisions, your earnings will be determined by your pre-tax income and the tax chosen by your group. There will be five members in each group and the majority vote will determine the tax for all members of your group. For each of the thirteen decisions you are re-randomized into a different group. The members of your group will be anonymous to you. None of you will know the identity of your group members.

Your pre-tax income in this section of the experiment will be determined by drawing a card from a set of five cards. The pre-tax incomes recorded on the five cards are as follows: $\$ 10$, $\$ 20, \$ 30, \$ 40$, and $\$ 50$. Your income card is private information and you should not disclose it to other participants at any time.

[Stop for the drawing of your pre-tax income card].

Note that in each group there will be one member with each pre-tax income level. Thus, before taxes are paid the total income in each group is $\$ 150$ and the average income of the group is $\$ 30$. Each of you will keep this same pre-tax income for all thirteen decisions in this section of the experiment.

Whether you pay Tax 1 or Tax 2 on your pre-tax income depends on the majority vote of your group. For each of the thirteen decisions you will be given a Tax Table that summarizes the tax that is paid by each member of your group and the resulting after-tax income.

Your Section 3 Record Sheet shows thirteen decisions. Each decision is a paired choice between "Tax 1" and "Tax 2". You will record your group number for each decision in the second column and your tax choice in the third column. Only one of the thirteen choices will be used to determine your earnings for this section. Next I will explain how these choices affect your earnings for this section of the experiment.

A set of thirteen cards labeled 1 through 13 will be used to determine payoffs. After all participants have made their choices, one of the participants will be selected to draw a card to determine which one of the thirteen decisions will be used. Again, even though you make thirteen decisions, only one of these decides your earnings, but you do not know in advance which decision will be used. Note that each decision has an equal chance of determining your earnings for this section. Your after-tax income from the binding decision is yours to keep and will be paid to you in cash.

You may not confer with other participants in making your decisions at any time. When all participants have recorded their votes for the taxes they prefer on both their Section 3 Record Sheets and their thirteen Decision Sheets, a monitor will come by and check that the votes are 
correctly recorded on the Record and Decision Sheets. A monitor will tally the votes for each group and record the outcome of each group's majority vote on an overhead transparency. The outcome will be displayed to everyone only after all participants have recorded their decisions.

This is the end of the instructions for this section, if you have any questions on this section of the instructions please ask them now. An experimenter will distribute the Tax Tables for the thirteen decisions at this time. When you have made your thirteen choices, please turn your Record and Decisions Sheets face down so that an experimenter may collect them. You have 30 minutes to complete the thirteen decisions.

[New page]

Group Number

Participant ID

\section{Decision 1}

Tax Table

The tax you pay on your pre-tax income will be one of two types. The following table summarizes the tax that is paid for each income level.

\begin{tabular}{|c|c|c|c|c|}
\hline \multirow[b]{2}{*}{$\begin{array}{l}\text { Pre-tax } \\
\text { Income }\end{array}$} & \multicolumn{2}{|c|}{ Tax 1} & \multicolumn{2}{|c|}{ Tax 2} \\
\hline & Tax & $\begin{array}{c}\text { After-Tax } \\
\text { Income }\end{array}$ & Tax & $\begin{array}{c}\text { After-Tax } \\
\text { Income }\end{array}$ \\
\hline$\$ 10.00$ & $\$ \$ 5.00$ & $\$ 5.00$ & $\$ 1.00$ & $\$ 99.00$ \\
\hline$\$ 20.00$ & $\$ 5.00$ & $\$ 15.00$ & $\$ 6.00$ & $\$ 14.00$ \\
\hline$\$ 30.00$ & $\$ 5.00$ & $\$ 25.00$ & $\$ 6.00$ & $\$ 24.00$ \\
\hline$\$ 40.00$ & $\$ 5.00$ & $\$ 35.00$ & $\$ 6.00$ & $\$ 34.00$ \\
\hline$\$ 50.00$ & $\$ 5.00$ & $\$ 45.00$ & $\$ 6.00$ & $\$ 44.00$ \\
\hline Total & $\$ 25.00$ & $\$ 125.00$ & $\$ 25.00$ & $\$ 125.00$ \\
\hline
\end{tabular}

Your Vote

Circle one of the following: Tax 1 or $\quad$ Tax 2 
[New page]

\section{Decision 2}

Tax Table

The tax you pay on your pre-tax income will be one of two types. The following table summarizes the tax that is paid for each income level.

\begin{tabular}{|c|c|c|c|c|}
\hline \multirow[b]{2}{*}{$\begin{array}{l}\text { Pre-tax } \\
\text { Income } \\
\end{array}$} & \multicolumn{2}{|c|}{ Tax 1} & \multicolumn{2}{|c|}{ Tax 2} \\
\hline & Tax & $\begin{array}{c}\text { After-Tax } \\
\text { Income }\end{array}$ & Tax & $\begin{array}{c}\text { After-Tax } \\
\text { Income }\end{array}$ \\
\hline$\$ 10.00$ & $\$ 5.00$ & $\$ 5.00$ & $\$ 8.00$ & $\$ 2.00$ \\
\hline$\$ 20.00$ & $\$ 5.00$ & $\$ 15.00$ & $\$ 15.00$ & $\$ 5.00$ \\
\hline$\$ 30.00$ & $\$ 5.00$ & $\$ 25.00$ & $-\$ 7.00$ & $\$ 37.00$ \\
\hline$\$ 40.00$ & $\$ 5.00$ & $\$ 35.00$ & $\$ 5.00$ & $\$ 35.00$ \\
\hline$\$ 50.00$ & $\$ 5.00$ & $\$ 45.00$ & $\$ 4.00$ & $\$ 46.00$ \\
\hline Total & $\$ 25.00$ & $\$ 125.00$ & $\$ 25.00$ & $\$ 125.00$ \\
\hline
\end{tabular}

Your Vote

Circle one of the following: $\quad$ Tax 1 or $\quad$ Tax 2

[New page]

\section{Decision 3}

Tax Table

The tax you pay on your pre-tax income will be one of two types. The following table summarizes the tax that is paid for each income level.

\begin{tabular}{|c|c|c|c|c|}
\hline \multirow[b]{2}{*}{$\begin{array}{l}\text { Pre-tax } \\
\text { Income } \\
\end{array}$} & \multicolumn{2}{|c|}{ Tax 1} & \multicolumn{2}{|c|}{ Tax 2} \\
\hline & Tax & $\begin{array}{c}\text { After-Tax } \\
\text { Income }\end{array}$ & Tax & $\begin{array}{l}\text { After-Tax } \\
\text { Income }\end{array}$ \\
\hline$\$ 10.00$ & $\$ 5.00$ & $\$ 5.00$ & $-\$ 15.00$ & $\$ 25.00$ \\
\hline$\$ 20.00$ & $\$ 5.00$ & $\$ 15.00$ & $\$ 3.00$ & $\$ 17.00$ \\
\hline$\$ 30.00$ & $\$ 5.00$ & $\$ 25.00$ & $\$ 7.00$ & $\$ 23.00$ \\
\hline$\$ 40.00$ & $\$ 5.00$ & $\$ 35.00$ & $\$ 11.00$ & $\$ 29.00$ \\
\hline$\$ 50.00$ & $\$ 5.00$ & $\$ 45.00$ & $\$ 25.00$ & $\$ 25.00$ \\
\hline Total & $\$ 25.00$ & $\$ 125.00$ & $\$ 31.00$ & $\$ 119.00$ \\
\hline
\end{tabular}

Your Vote

Circle one of the following: $\quad$ Tax 1 or $\quad$ Tax 2 
[New page]

\section{Decision 4}

Tax Table

The tax you pay on your pre-tax income will be one of two types. The following table summarizes the tax that is paid for each income level.

\begin{tabular}{|c|c|c|c|c|}
\hline \multirow[b]{2}{*}{$\begin{array}{l}\text { Pre-tax } \\
\text { Income }\end{array}$} & \multicolumn{2}{|c|}{ Tax 1} & \multicolumn{2}{|c|}{ Tax 2} \\
\hline & Tax & $\begin{array}{c}\text { After-Tax } \\
\text { Income }\end{array}$ & Tax & $\begin{array}{c}\text { After-Tax } \\
\text { Income }\end{array}$ \\
\hline$\$ 10.00$ & $\$ 5.00$ & $\$ 5.00$ & $\$ 8.00$ & $\$ 2.00$ \\
\hline$\$ 20.00$ & $\$ 5.00$ & $\$ 15.00$ & $\$ 4.00$ & $\$ 16.00$ \\
\hline$\$ 30.00$ & $\$ 5.00$ & $\$ 25.00$ & $-\$ 9.00$ & $\$ 39.00$ \\
\hline$\$ 40.00$ & $\$ 5.00$ & $\$ 35.00$ & $\$ 8.00$ & $\$ 32.00$ \\
\hline$\$ 50.00$ & $\$ 5.00$ & $\$ 45.00$ & $\$ 1.00$ & $\$ 49.00$ \\
\hline Total & $\$ 25.00$ & $\$ 125.00$ & $\$ 12.00$ & $\$ 138.00$ \\
\hline
\end{tabular}

Your Vote

Circle one of the following: $\quad$ Tax 1 or $\quad$ Tax 2

[New page]

\section{Decision 5 \\ Tax Table}

The tax you pay on your pre-tax income will be one of two types. The following table summarizes the tax that is paid for each income level.

\begin{tabular}{|c|c|c|c|c|}
\hline \multirow[b]{2}{*}{$\begin{array}{l}\text { Pre-tax } \\
\text { Income }\end{array}$} & \multicolumn{2}{|c|}{ Tax 1} & \multicolumn{2}{|c|}{ Tax 2} \\
\hline & Tax & $\begin{array}{l}\text { After-Tax } \\
\text { Income }\end{array}$ & Tax & $\begin{array}{l}\text { After-Tax } \\
\text { Income }\end{array}$ \\
\hline$\$ 10.00$ & $\$ 5.00$ & $\$ 5.00$ & $-\$ 17.00$ & $\$ 27.00$ \\
\hline$\$ 20.00$ & $\$ 5.00$ & $\$ 15.00$ & $-\$ 4.00$ & $\$ 24.00$ \\
\hline$\$ 30.00$ & $\$ 5.00$ & $\$ 25.00$ & $-\$ 2.00$ & $\$ 32.00$ \\
\hline$\$ 40.00$ & $\$ 5.00$ & $\$ 35.00$ & $\$ 38.00$ & $\$ 2.00$ \\
\hline$\$ 50.00$ & $\$ 5.00$ & $\$ 45.00$ & $\$ 20.00$ & $\$ 30.00$ \\
\hline Total & $\$ 25.00$ & $\$ 125.00$ & $\$ 35.00$ & $\$ 115.00$ \\
\hline
\end{tabular}

Your Vote

Circle one of the following: $\quad$ Tax 1 or $\quad$ Tax 2 
[New page]

\section{Decision 6}

Tax Table

The tax you pay on your pre-tax income will be one of two types. The following table summarizes the tax that is paid for each income level.

\begin{tabular}{|c|c|c|c|c|}
\hline \multirow[b]{2}{*}{$\begin{array}{l}\text { Pre-tax } \\
\text { Income }\end{array}$} & \multicolumn{2}{|c|}{ Tax 1} & \multicolumn{2}{|c|}{ Tax 2} \\
\hline & Tax & $\begin{array}{c}\text { After-Tax } \\
\text { Income }\end{array}$ & Tax & $\begin{array}{c}\text { After-Tax } \\
\text { Income }\end{array}$ \\
\hline$\$ 10.00$ & $\$ 5.00$ & $\$ 5.00$ & $\$ 6.00$ & $\$ 4.00$ \\
\hline$\$ 20.00$ & $\$ 5.00$ & $\$ 15.00$ & $\$ 6.00$ & $\$ 14.00$ \\
\hline$\$ 30.00$ & $\$ 5.00$ & $\$ 25.00$ & $\$ 6.00$ & $\$ 24.00$ \\
\hline$\$ 40.00$ & $\$ 5.00$ & $\$ 35.00$ & $\$ 6.00$ & $\$ 34.00$ \\
\hline$\$ 50.00$ & $\$ 5.00$ & $\$ 45.00$ & $\$ 6.00$ & $\$ 44.00$ \\
\hline Total & $\$ 25.00$ & $\$ 125.00$ & $\$ 30.00$ & $\$ 120.00$ \\
\hline
\end{tabular}

Your Vote

Circle one of the following: $\quad$ Tax 1 or $\quad$ Tax 2

[New page]

Decision 7

Tax Table

The tax you pay on your pre-tax income will be one of two types. The following table summarizes the tax that is paid for each income level.

\begin{tabular}{|c|c|c|c|c|}
\hline \multirow[b]{2}{*}{$\begin{array}{l}\text { Pre-tax } \\
\text { Income }\end{array}$} & \multicolumn{2}{|c|}{ Tax 1} & \multicolumn{2}{|c|}{ Tax 2} \\
\hline & Tax & $\begin{array}{l}\text { After-Tax } \\
\text { Income }\end{array}$ & Tax & $\begin{array}{l}\text { After-Tax } \\
\text { Income }\end{array}$ \\
\hline$\$ 10.00$ & $\$ 5.00$ & $\$ 5.00$ & $\$ 1.00$ & $\$ 9.00$ \\
\hline$\$ 20.00$ & $\$ 5.00$ & $\$ 15.00$ & $\$ 12.00$ & $\$ 8.00$ \\
\hline$\$ 30.00$ & $\$ 5.00$ & $\$ 25.00$ & $\$ 14.00$ & $\$ 16.00$ \\
\hline$\$ 40.00$ & $\$ 5.00$ & $\$ 35.00$ & $\$ 0.00$ & $\$ 40.00$ \\
\hline$\$ 50.00$ & $\$ 5.00$ & $\$ 45.00$ & $\$ 6.00$ & $\$ 44.00$ \\
\hline Total & $\$ 25.00$ & $\$ 125.00$ & $\$ 33.00$ & $\$ 117.00$ \\
\hline
\end{tabular}

Your Vote

Circle one of the following: Tax 1 or $\quad$ Tax 2 
[New page]

\section{Decision 8}

Tax Table

The tax you pay on your pre-tax income will be one of two types. The following table summarizes the tax that is paid for each income level.

\begin{tabular}{|c|c|c|c|c|}
\hline \multirow[b]{2}{*}{$\begin{array}{l}\text { Pre-tax } \\
\text { Income }\end{array}$} & \multicolumn{2}{|c|}{ Tax 1} & \multicolumn{2}{|c|}{ Tax 2} \\
\hline & Tax & $\begin{array}{l}\text { After-Tax } \\
\text { Income }\end{array}$ & Tax & $\begin{array}{l}\text { After-Tax } \\
\text { Income }\end{array}$ \\
\hline$\$ 10.00$ & $\$ 5.00$ & $\$ 5.00$ & $\$ 6.00$ & $\$ 4.00$ \\
\hline$\$ 20.00$ & $\$ 5.00$ & $\$ 15.00$ & $\$ 3.00$ & $\$ 17.00$ \\
\hline$\$ 30.00$ & $\$ 5.00$ & $\$ 25.00$ & $\$ 0.00$ & $\$ 30.00$ \\
\hline$\$ 40.00$ & $\$ 5.00$ & $\$ 35.00$ & $\$ 15.00$ & $\$ 25.00$ \\
\hline$\$ 50.00$ & $\$ 5.00$ & $\$ 45.00$ & $\$ 6.00$ & $\$ 44.00$ \\
\hline Total & $\$ 25.00$ & $\$ 125.00$ & $\$ 30.00$ & $\$ 120.00$ \\
\hline
\end{tabular}

Your Vote

Circle one of the following: $\quad$ Tax 1 or $\quad$ Tax 2

[New page]

\section{Decision 9}

Tax Table

The tax you pay on your pre-tax income will be one of two types. The following table summarizes the tax that is paid for each income level.

\begin{tabular}{|c|c|c|c|c|}
\hline \multirow[b]{2}{*}{$\begin{array}{l}\text { Pre-tax } \\
\text { Income }\end{array}$} & \multicolumn{2}{|c|}{ Tax 1} & \multicolumn{2}{|c|}{ Tax 2} \\
\hline & Tax & $\begin{array}{l}\text { After-Tax } \\
\text { Income }\end{array}$ & Tax & $\begin{array}{l}\text { After-Tax } \\
\text { Income }\end{array}$ \\
\hline$\$ 10.00$ & $\$ 5.00$ & $\$ 5.00$ & $-\$ 25.00$ & $\$ 35.00$ \\
\hline$\$ 20.00$ & $\$ 5.00$ & $\$ 15.00$ & $-\$ 10.00$ & $\$ 30.00$ \\
\hline$\$ 30.00$ & $\$ 5.00$ & $\$ 25.00$ & $\$ 1.00$ & $\$ 29.00$ \\
\hline$\$ 40.00$ & $\$ 5.00$ & $\$ 35.00$ & $\$ 11.00$ & $\$ 29.00$ \\
\hline$\$ 50.00$ & $\$ 5.00$ & $\$ 45.00$ & $\$ 48.00$ & $\$ 2.00$ \\
\hline Total & $\$ 25.00$ & $\$ 125.00$ & $\$ 25.00$ & $\$ 125.00$ \\
\hline
\end{tabular}

Your Vote

Circle one of the following: $\quad$ Tax 1 or $\quad$ Tax 2 
[New page]

\section{Decision 10 \\ Tax Table}

The tax you pay on your pre-tax income will be one of two types. The following table summarizes the tax that is paid for each income level.

\begin{tabular}{|c|c|c|c|c|}
\hline \multirow[b]{2}{*}{$\begin{array}{l}\text { Pre-tax } \\
\text { Income }\end{array}$} & \multicolumn{2}{|c|}{ Tax 1} & \multicolumn{2}{|c|}{ Tax 2} \\
\hline & Tax & $\begin{array}{l}\text { After-Tax } \\
\text { Income }\end{array}$ & Tax & $\begin{array}{l}\text { After-Tax } \\
\text { Income }\end{array}$ \\
\hline$\$ 10.00$ & $\$ 5.00$ & $\$ 5.00$ & $-\$ 13.00$ & $\$ 23.00$ \\
\hline$\$ 20.00$ & $\$ 5.00$ & $\$ 15.00$ & $-\$ 4.00$ & $\$ 24.00$ \\
\hline$\$ 30.00$ & $\$ 5.00$ & $\$ 25.00$ & $\$ 28.00$ & $\$ 2.00$ \\
\hline$\$ 40.00$ & $\$ 5.00$ & $\$ 35.00$ & $\$ 9.00$ & $\$ 31.00$ \\
\hline$\$ 50.00$ & $\$ 5.00$ & $\$ 45.00$ & $\$ 17.00$ & $\$ 23.00$ \\
\hline Total & $\$ 25.00$ & $\$ 12500$ & $\$ 3700$ & $\$ 10300$ \\
\hline
\end{tabular}

Your Vote

Circle one of the following: $\quad$ Tax 1 or $\quad$ Tax 2

[New page]

\section{Decision 11}

Tax Table

The tax you pay on your pre-tax income will be one of two types. The following table summarizes the tax that is paid for each income level.

\begin{tabular}{|c|c|c|c|c|}
\hline \multirow[b]{2}{*}{$\begin{array}{l}\text { Pre-tax } \\
\text { Income }\end{array}$} & \multicolumn{2}{|c|}{ Tax 1} & \multicolumn{2}{|c|}{ Tax 2} \\
\hline & Tax & $\begin{array}{l}\text { After-Tax } \\
\text { Income }\end{array}$ & Tax & $\begin{array}{l}\text { After-Tax } \\
\text { Income }\end{array}$ \\
\hline$\$ 10.00$ & $\$ 5.00$ & $\$ 5.00$ & $-\$ 15.00$ & $\$ 25.00$ \\
\hline$\$ 20.00$ & $\$ 5.00$ & $\$ 15.00$ & $-\$ 5.00$ & $\$ 25.00$ \\
\hline$\$ 30.00$ & $\$ 5.00$ & $\$ 25.00$ & $\$ 5.00$ & $\$ 25.00$ \\
\hline$\$ 40.00$ & $\$ 5.00$ & $\$ 35.00$ & $\$ 15.00$ & $\$ 25.00$ \\
\hline$\$ 50.00$ & $\$ 5.00$ & $\$ 45.00$ & $\$ 25.00$ & $\$ 25.00$ \\
\hline Total & $\$ 25.00$ & $\$ 125.00$ & $\$ 25.00$ & $\$ 125.00$ \\
\hline
\end{tabular}

Your Vote

Circle one of the following: $\quad$ Tax 1 or $\quad$ Tax 2 
[New page]

\section{Decision 12}

\section{Tax Table}

The tax you pay on your pre-tax income will be one of two types. The following table summarizes the tax that is paid for each income level.

\begin{tabular}{|c|c|c|c|c|}
\hline \multirow[b]{2}{*}{$\begin{array}{l}\text { Pre-tax } \\
\text { Income }\end{array}$} & \multicolumn{2}{|c|}{ Tax 1} & \multicolumn{2}{|c|}{$\operatorname{Tax} 2$} \\
\hline & Tax & $\begin{array}{c}\text { After-Tax } \\
\text { Income }\end{array}$ & Tax & $\begin{array}{c}\text { After-Tax } \\
\text { Income }\end{array}$ \\
\hline$\$ 10.00$ & $\$ 5.00$ & $\$ 5.00$ & $-\$ 10.00$ & $\$ 20.00$ \\
\hline$\$ 20.00$ & $\$ 5.00$ & $\$ 15.00$ & $\$ 0.00$ & $\$ 20.00$ \\
\hline$\$ 30.00$ & $\$ 5.00$ & $\$ 25.00$ & $\$ 10.00$ & $\$ 20.00$ \\
\hline$\$ 40.00$ & $\$ 5.00$ & $\$ 35.00$ & $\$ 20.00$ & $\$ 20.00$ \\
\hline$\$ 50.00$ & $\$ 5.00$ & $\$ 45.00$ & $\$ 30.00$ & $\$ 20.00$ \\
\hline Total & $\$ 25.00$ & $\$ 125.00$ & $\$ 50.00$ & $\$ 100.00$ \\
\hline
\end{tabular}

Your Vote

Circle one of the following: $\quad$ Tax 1 or $\quad \operatorname{Tax} 2$

[New page]

\section{Decision 13 \\ Tax Table}

The tax you pay on your pre-tax income will be one of two types. The following table summarizes the tax that is paid for each income level.

\begin{tabular}{|c|c|c|c|c|}
\hline \multirow[b]{2}{*}{$\begin{array}{l}\text { Pre-tax } \\
\text { Income }\end{array}$} & \multicolumn{2}{|c|}{ Tax 1} & \multicolumn{2}{|c|}{ Tax 2} \\
\hline & Tax & $\begin{array}{c}\text { After-Tax } \\
\text { Income }\end{array}$ & Tax & $\begin{array}{l}\text { After-Tax } \\
\text { Income }\end{array}$ \\
\hline$\$ 10.00$ & $\$ 5.00$ & $\$ 5.00$ & $-\$ 1.00$ & $\$ 11.00$ \\
\hline$\$ 20.00$ & $\$ 5.00$ & $\$ 15.00$ & $\$ 9.00$ & $\$ 11.00$ \\
\hline$\$ 30.00$ & $\$ 5.00$ & $\$ 25.00$ & $\$ 9.00$ & $\$ 21.00$ \\
\hline$\$ 40.00$ & $\$ 5.00$ & $\$ 35.00$ & $\$ 9.00$ & $\$ 31.00$ \\
\hline$\$ 50.00$ & $\$ 5.00$ & $\$ 45.00$ & $\$ 9.00$ & $\$ 41.00$ \\
\hline Total & $\$ 25.00$ & $\$ 125.00$ & $\$ 35.00$ & $\$ 115.00$ \\
\hline
\end{tabular}

Your Vote

Circle one of the following: $\quad$ Tax 1 or $\quad$ Tax 2 
[New page]

\section{Participant ID}

Section 3 Record Sheet

\begin{tabular}{|c|c|c|c|c|c|c|}
\hline Decision & $\begin{array}{l}\text { Group } \\
\text { Number }\end{array}$ & $\begin{array}{c}\text { Your Vote } \\
\text { (Tax } 1 \text { or Tax 2) }\end{array}$ & $\begin{array}{c}\text { Group } \\
\text { Majority } \\
\text { Vote } \\
\text { (Tax } 1 \text { or Tax 2) }\end{array}$ & $\begin{array}{c}\text { Your } \\
\text { Pre-tax } \\
\text { Income } \\
\text { (income card) }\end{array}$ & $\begin{array}{l}\text { Your } \\
\text { Taxes } \\
\text { Paid* }\end{array}$ & $\begin{array}{c}\text { Your } \\
\text { After-tax } \\
\text { Income }\end{array}$ \\
\hline 1 & & & & & & \\
\hline 2 & & & & & & \\
\hline 3 & & & & & & \\
\hline 4 & & & & & & \\
\hline 5 & & & & & & \\
\hline 6 & & & & & & \\
\hline 7 & & & & & & \\
\hline 8 & & & & & & \\
\hline 9 & & & & & & \\
\hline 10 & & & & & & \\
\hline 11 & & & & & & \\
\hline 12 & & & & & & \\
\hline 13 & & & & & & \\
\hline
\end{tabular}

* The amount you pay in taxes is determined by your income level and the majority vote for Tax 1or Tax 2. 
[New page]

\section{Earnings Determination}

\section{Section 3 Earnings:}

Note the randomized groups on the overhead for each Tax Table Decision and each group's majority vote. Please verify that your recorded group number for each decision corresponds to that on the overhead. At this time, a card will be randomly chosen that will designate which of the thirteen decisions will determine your earnings. [Stop for drawing of the card and calculation of the majority vote for the binding Tax Table decision.] Please record on your cumulative record sheet the binding Tax Table Decision number chosen and your group's majority vote. Please calculate your earnings and a monitor will come by to check your calculations.

\section{Section 1 Earnings:}

At this time a participant will be randomly selected to toss the coin while two other participants will verify with the monitor whether the toss landed as tales or heads.

[Stop for coin toss.] Record the toss of the coin [2.5 for heads (success) and 0 for tails (failure)] and calculate your Section 1 earnings at this time. A monitor will come by and check your calculations.

\section{Section 2 Earnings:}

At this time participants will randomly draw the code ID chips from the bucket. The drawn code ID's will be recorded on the overhead. Those participants with the drawn code ID's are the allocators and will earn the allocation amount that they allocated to themselves. Those participants whose code ID's are not drawn are the recipients. Your earnings will be randomly selected from the chosen allocators' recipient sheets. [Stop for drawing of chips.] If your chip was drawn please record your earnings at this time. If your code ID was not drawn, then record the recipient's allocation as your earnings from the sheet you receive. A monitor will come by and check your calculations. 
[New page]

\section{Participant ID}

\section{Cumulative Record Sheet}

\begin{tabular}{|l|l|}
\hline $\begin{array}{l}\text { Instruction Section 1: } \\
\text { Total amount not invested and the result of the investment. }\end{array}$ & $\$$ \\
\hline $\begin{array}{l}\text { Instruction Section 2: } \\
\text { The cash allocation to yourself if you are an allocator or that } \\
\text { allocated by a randomly paired participant if you are a recipient. }\end{array}$ & $\$$ \\
\hline $\begin{array}{l}\text { Instruction Section 3: } \\
\text { After-tax income from binding round } \\
\text { (Your pre-tax income was \$_. } \\
\text { (The binding Tax Table was number _.) }\end{array}$ & $\$$ \\
\hline Add \$4 if on time for the experiment. & $\$$ \\
\hline Add \$4 for completion of post-experiment questionnaire. & $\$$ \\
\hline Your total cash earnings for participation is this session. & $\$$ \\
\hline
\end{tabular}

[New page]

\section{Participant ID}

\section{Post-Experiment Questionnaire}

This questionnaire is designed to collect general information. Such information may help us better understand differences found between participants in this experiment.

1. What year are you in university (e.g., 2nd, 3rd, 4th, Masters, Ph.D.)?

2. What is your major or concentration (e.g., accounting, economics, etc.)?

3. What is your sex? male female

4. What is your age? years 
5a. What are your means of financial support (check all that apply)? self supported

parent or relative spouse or significant other financial aid or other loans scholarship other

5b. Referring to question 5a., what is your total household income (check one)?

$\$ 0-\$ 25,000$
$\$ 25,001-\$ 50,000$
$\$ 50,001-\$ 75,000$
$\$ 75,001-\$ 100,000$
More than $\$ 100,000$

5c. What is your primary means of financial support (check only one)? self supported parent or relative spouse or significant other financial aid or other loans scholarship other

6. How many finance and economics courses have you successfully completed at the university level? courses

7. How many finance and economics courses are you currently enrolled in? courses

8. How interesting did you find this experiment? (circle the appropriate number) Not very Interesting $1---1$ $-2--------3$ 3--------4---------5 ---------6---------7 -8--------9--------10---------11

Very Interesting

9. For the time spent, how would you characterize the amount of money earned for participating in this experiment? (circle the appropriate number)

Nominal

Considerable

Amount Amount 1--------2----------3---------4---------5---------6---------7---------8---------9--------10---------11

10. Would you, in general, prefer an income tax structure in the United States where everyone pays the same tax, regardless of income or wealth, or a tax that varies across income levels?

11. Is there any circumstance in which your answer to question 10 would change? Why? 


\section{References}

Ackert, Lucy F., Bryan K. Church, and Basil Englis. 2002. The asset allocation decision and investor heterogeneity: A puzzle? Journal of Economic Behavior and Organization 47(4): 423-433.

Ackert, Lucy F., Ann B. Gillette, Jorge Martinez-Vazquez, and Mark Rider. 2007. Voting on tax policy design: A test of the selfish versus social preferences hypothesis. Public Finance Review 35(2): 263-284.

Ackert, Lucy F., Jorge Martinez-Vazquez, and Mark Rider. 2007. Social preferences and tax policy design: Some experimental evidence. Economic Inquiry 45(3): 487-501.

Baker, Ronald J. II, Susan K. Laury, and Arlington W. Williams. 2007. Comparing small-group and individual behavior in lottery-choice experiments. Working Paper 2007-018, Center for Applied Economics and Policy Research.

Barber, Brad M. and Terrance Odean. 2001. Boys will be boys: Gender, overconfidence, and common stock investment. Quarterly Journal of Economics 116(1): 261-292.

Bolton, Gary E., Elena Katok, and Rami Zwick. 1998. Dictator game giving: Rules of fairness versus acts of kindness. International Journal of Game Theory 27(2): 269-299.

Bolton, Gary E., and Axel Ockenfels. 2000. ERC: A theory of equity, reciprocity, and competition. The American Economic Review 90(1): 166-193.

Charness, Gary, and Uri Gneezy. 2007. Strong evidence for gender differences in investment. SSRN Working Paper 648735.

Charness, Gary and Garance Genicot. 2004. An experimental test of risk-sharing arrangements. Working Paper. 
Charness, Gary and Matthew Rabin. 2002. Understanding social preferences with simple tests. The Quarterly Journal of Economics 117(3): 817-869.

Charness, Gary and Marie-Claire Villeval, 2007. Cooperation, competition, and risk attitudes: An intergenerational field and laboratory experiment. Working Paper 2574, IZA Institute for the Study of Labor.

Clotfelter, Charles T. 1983. Tax evasion and tax rates: an analysis of individual returns. Review of Economics and Statistics 65 (3): 363-73.

Collier, Paul and Jan Willem Gunning. 1999. Explaining the African growth performance. Journal of Economic Literature 37(1): 64-111.

Cox, James C. and Cary A. Deck. 2006. When are women more generous than men? Economic Inquiry 44(4): 587-598.

Cox, James C., Daniel Friedman, and Steven Gjerstad. 2007. A tractable model of reciprocity and fairness. Games and Economic Behavior 59(1): 17-45.

Cox, James C., Daniel Friedman, and Vjollca Sadiraj. 2008. Revealed altruism. Econometrica 76(1): 31-69.

Croson, Rachel, and Uri Gneezy. 2004. Gender differences in preferences. Working paper, University of Texas at Dallas.

Eckel, Catherine C. and Philip J. Grossman. 1998. Are women less selfish than men? Evidence from dictator experiments. The Economic Journal 108(448): 726-735.

Engelmann, Dirk and Martin Strobel. 2004. Inequality aversion, efficiency, and maximumin preferences in simple distribution experiments. American Ecnomic Review 94 (4):857-69. 
Engelmann, Dirk and Martin Strobel. 2006. Inequality aversion, efficiency, and maximumin preferences in simple distribution experiments: Reply. American Ecnomic Review 96 (5):1918-25.

Fehr, Ernst, Helen Bernhard, and Bettina Rockenbach. 2008. Egalitarianism in young children. Nature 454:1079-1084.

Fehr, Ernst and Klaus M. Schmidt. 1999. A theory of fairness, competition, and cooperation. The Quarterly Journal of Economics 114(3): 817-868.

Frank, Robert, Thomas Gilovich, and Dennis T. Regan. 1993. Does studying economics inhibit cooperation? Journal of Economic Perspectives 7(2):159-171.

Forsythe, Robert, Joel Horowitz, N. E. Savin, and Martin Sefton. 1994. Fairness in simple bargaining experiments. Games and Economic Behavior 6(3): 347-369.

Harrison, Glenn W., Morten Igel Lau, E. Elisabet Rutström, and Marcela Tarazona-Gómez. 2005. Preferences over social risk. Working Paper 05-06, University of Central Florida.

Henrich, Joseph, Robert Boyd, Samuel Bowles, Colin Camerer, Ernst Fehr, and Herbert Gintis (eds). 2004. Foundations of Human Sociality: Economic Experiments and Ethnographic Evidence from Fifteen Small-Scale Societies, New York: Oxford University Press.

Hey, John D. and Jinkwon Lee. 2007. Do subjects remember the past? Applied Economics 37(1): $9-18$.

Hoffman, Elizabeth and M. Spitzer. 1985. Entitlements, rights, and fairness: an experimental examination of subjects' concepts of distributive justice. Journal of Legal Studies 14(2): 259-297.

Joulfaian, David and Mark Rider. 1996. Tax evasion in the presence of negative income tax rates. National Tax Journal 49(4): 553-70. 
Joulfaian, David and Mark Rider. 1998. Differential taxation and tax evasion by small business. National Tax Journal 51(4): 675-87.

Martinez-Vazquez, Jorge and Mark Rider. 2005. Multiple modes of tax evasion: theory and evidence. National Tax Journal 58(1): 51-76.

Murnighan, J. Keith and Michael Scott Saxon. 1998. Ultimatum bargaining by children and adults. Journal of Economic Psychology 19(4): 415-445.

Rabin, Matthew. 1993. Incorporating fairness into game theory and economics. American Economic Review 83(5): 1281-1302.

Rawls, John. 1971. A Theory of Justice, Cambridge, MA: Harvard University Press.

Rutström, E. Elisabet and Melonie B. Williams, 2000. Entitlements and fairness: an experimental study of distributive preferences. Journal of Economic Behavior and Organization 43(1): 75-89. 
Figure 1

Histogram of Investment in the Risky Asset

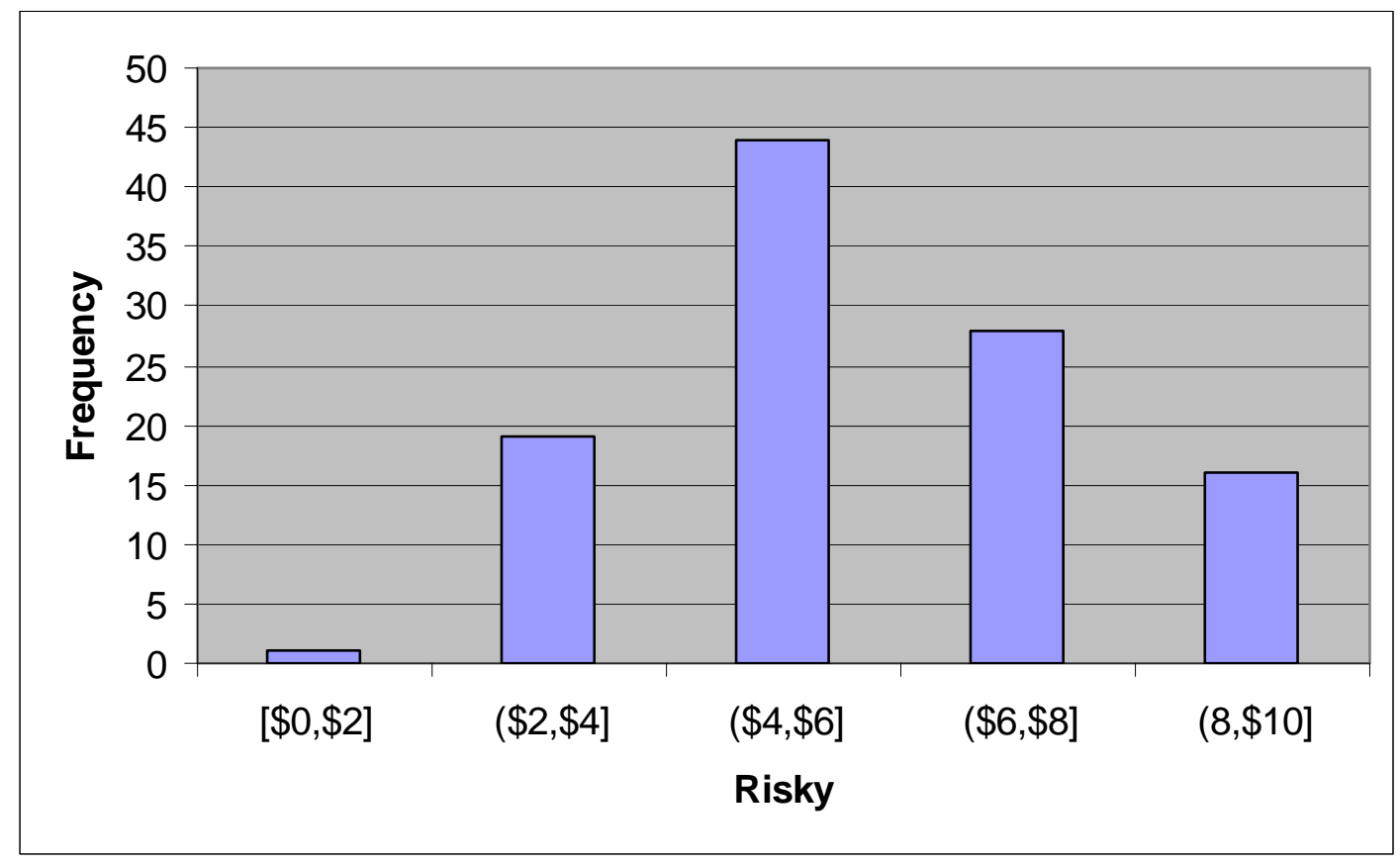


Figure 2

Histogram of Self Allocation

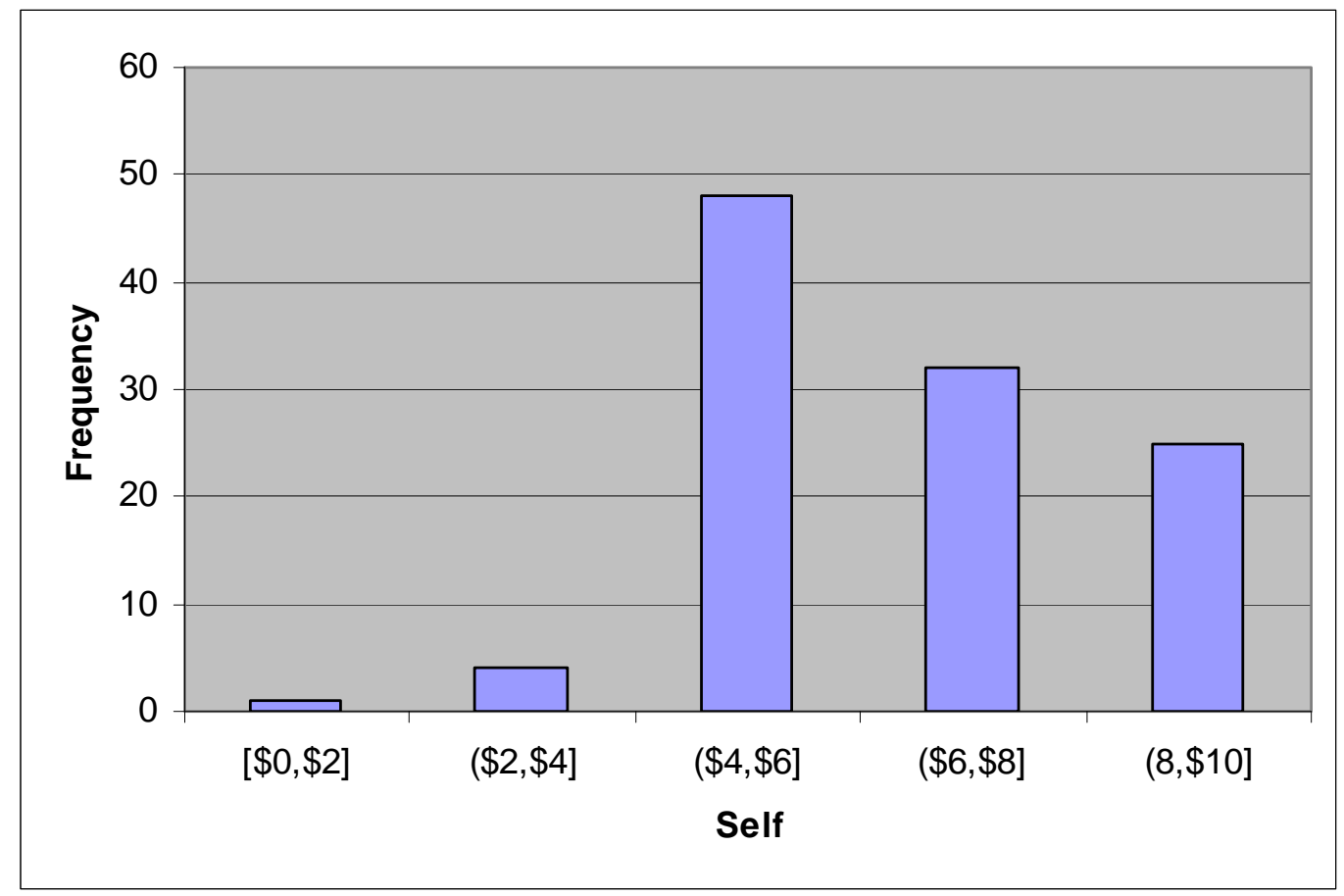


Figure 3

Relative frequency of sacrifice

\section{Social}

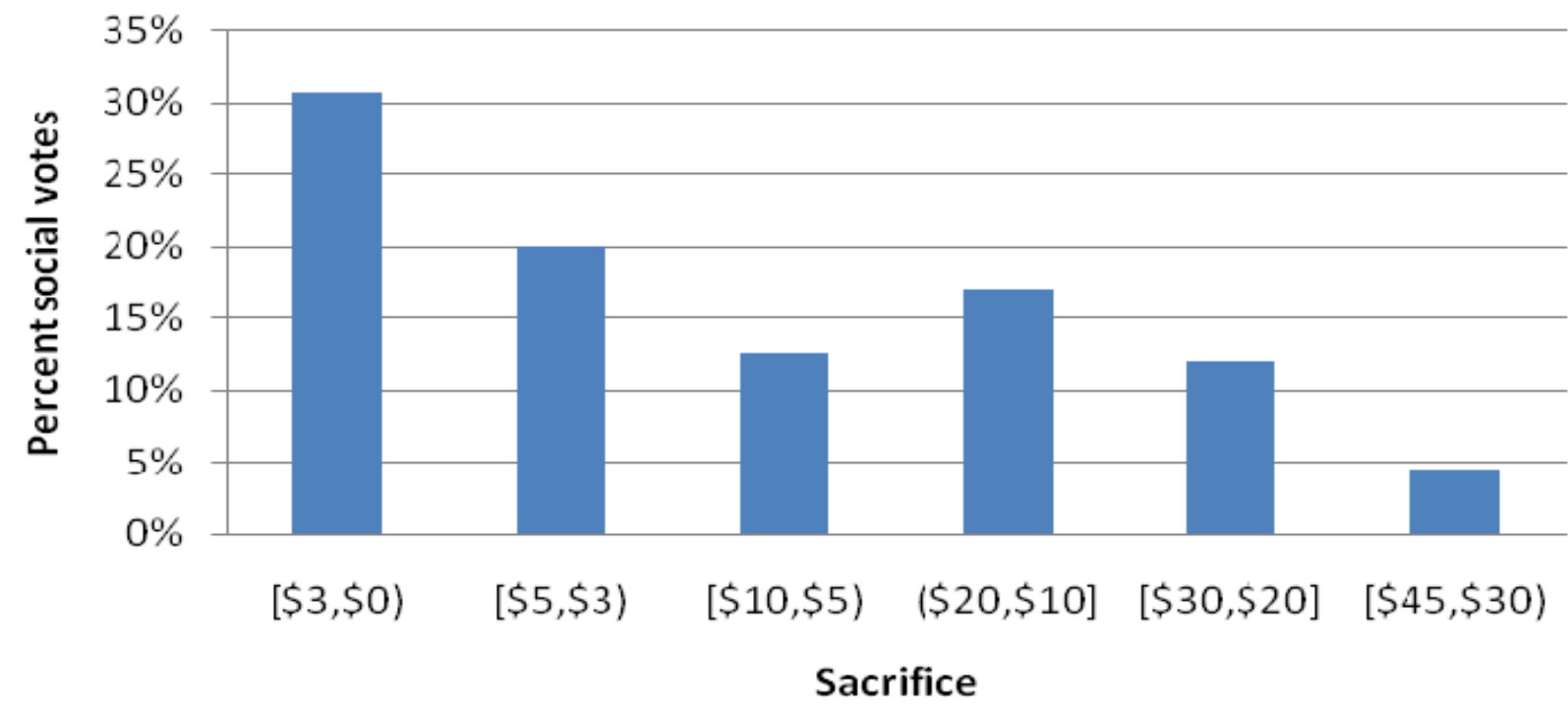


Figure 4

Histogram of social votes by status

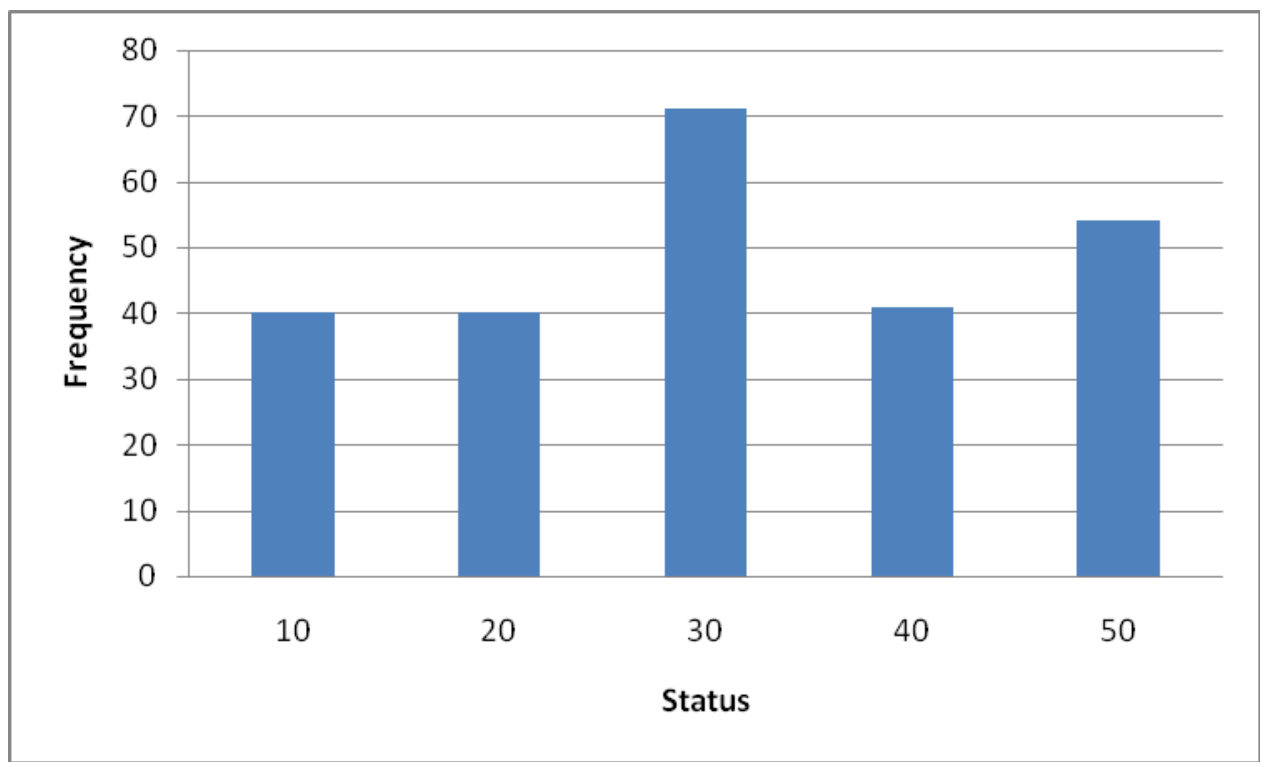


Table 1

Experimental Sessions

\begin{tabular}{c|cccc}
\hline $\begin{array}{c}\text { Experiment } \\
\text { Session }\end{array}$ & Participants & $\begin{array}{c}\text { Number of } \\
\text { Participants }\end{array}$ & $\begin{array}{c}\text { Coin Toss for } \\
\text { Section 1 }\end{array}$ \\
\hline 1 & Students & 20 & Heads \\
\hline 2 & Students & 20 & Tales \\
\hline 3 & Policy Group & 20 & Heads \\
\hline 4 & Policy Group & 20 & Tales \\
\hline 5 & Students & 10 & Heads \\
\hline 6 & Students & 20 & Heads
\end{tabular}


Table 2

Summary Statistics (means; standard deviations in parentheses)

\begin{tabular}{|c|c|c|c|}
\hline Variable & All & Students & Professionals \\
\hline Number of years in university & $\begin{array}{c}5.3 \\
(1.7)\end{array}$ & $\begin{array}{c}5.0 \\
(1.5)\end{array}$ & $\begin{array}{c}6.0 \\
(1.8)\end{array}$ \\
\hline Gender $($ female $=1.0)$ & $35 \%$ & $42 \%$ & $21 \%$ \\
\hline Number of economics courses & $\begin{array}{l}4.8 \\
(6.1)\end{array}$ & $\begin{array}{c}5.0 \\
(6.0)\end{array}$ & $\begin{array}{c}4.3 \\
(6.4)\end{array}$ \\
\hline Business majors & $65 \%$ & $57 \%$ & $82 \%$ \\
\hline Age & $\begin{array}{c}31.6 \\
(10.1)\end{array}$ & $\begin{array}{l}26.2 \\
(4.7)\end{array}$ & $\begin{array}{l}41.4 \\
(9.8)\end{array}$ \\
\hline \multicolumn{4}{|l|}{ Source of support } \\
\hline Self & $65 \%$ & $49 \%$ & $95 \%$ \\
\hline Parents & $24 \%$ & $35 \%$ & $5 \%$ \\
\hline Spouse & $7 \%$ & $12 \%$ & $0 \%$ \\
\hline Financial aid & $28 \%$ & $38 \%$ & $10.5 \%$ \\
\hline Scholarship & $30 \%$ & $43 \%$ & $5.3 \%$ \\
\hline Other & $5 \%$ & $7 \%$ & $0 \%$ \\
\hline \multicolumn{4}{|l|}{ Total household income } \\
\hline$\$ 0-\$ 25,000$ & $64 \%$ & $55 \%$ & $82 \%$ \\
\hline$\$ 25,001-\$ 50,000$ & $15 \%$ & $20 \%$ & $5 \%$ \\
\hline$\$ 50,001-\$ 75,000$ & $8 \%$ & $12 \%$ & $3 \%$ \\
\hline$\$ 75,001-\$ 100,000$ & $6 \%$ & $7 \%$ & $3 \%$ \\
\hline Greater than $\$ 100,000$ & $7 \%$ & $6 \%$ & $8 \%$ \\
\hline Number of observations & 107 & 69 & 38 \\
\hline
\end{tabular}


Table 3

OLS estimates of investment in the risky asset

\begin{tabular}{|c|c|c|c|c|c|c|}
\hline Variable & (1) & (2) & (3) & (4) & (5) & (6) \\
\hline Years in university & $\begin{array}{c}0.06 \\
(0.14)\end{array}$ & $\begin{array}{c}0.06 \\
(0.14)\end{array}$ & $\begin{array}{c}0.071 \\
(0.138)\end{array}$ & $\begin{array}{c}0.12 \\
(0.15)\end{array}$ & $\begin{array}{l}0.28^{*} \\
(0.15)\end{array}$ & $\begin{array}{l}0.28^{*} \\
(0.15)\end{array}$ \\
\hline Gender $($ female $=1)$ & $\begin{array}{c}-0.87 * * \\
(0.38)\end{array}$ & $\begin{array}{c}-0.87 * * \\
(0.38)\end{array}$ & $\begin{array}{c}-0.899 * * \\
(0.383)\end{array}$ & $\begin{array}{c}-0.94 * * \\
(0.39)\end{array}$ & $\begin{array}{c}-1.05^{* * *} \\
(0.40)\end{array}$ & $\begin{array}{c}-0.89 * * \\
(0.40)\end{array}$ \\
\hline Policy students & $\begin{array}{l}0.76^{*} \\
(0.47)\end{array}$ & $\begin{array}{l}0.77 * \\
(0.47)\end{array}$ & $\begin{array}{c}0.598 \\
(0.488)\end{array}$ & $\begin{array}{l}0.62 * \\
(0.49)\end{array}$ & $\begin{array}{c}1.23 * * * \\
(0.52)\end{array}$ & $\begin{array}{l}1.01^{*} \\
(0.56)\end{array}$ \\
\hline Economics courses & & $\begin{array}{c}0.01 \\
(0.04)\end{array}$ & $\begin{array}{l}-0.004 \\
(0.044)\end{array}$ & $\begin{array}{c}-0.01 \\
(0.045)\end{array}$ & $\begin{array}{c}0.02 \\
(0.05)\end{array}$ & $\begin{array}{c}0.03 \\
(0.05)\end{array}$ \\
\hline Business students & & & $\begin{array}{c}0.542 \\
(0.477)\end{array}$ & $\begin{array}{c}0.57 \\
(0.47)\end{array}$ & $\begin{array}{c}0.38 \\
(0.46)\end{array}$ & $\begin{array}{c}0.20 \\
(0.46)\end{array}$ \\
\hline Total household income & & & & $\begin{array}{c}0.19 \\
(0.16)\end{array}$ & $\begin{array}{c}0.07 \\
(0.15)\end{array}$ & $\begin{array}{l}-0.01 \\
(0.15)\end{array}$ \\
\hline Age & & & & & $\begin{array}{c}-0.01 * * \\
(0.003)\end{array}$ & $\begin{array}{c}-0.41^{* *} \\
(0.20)\end{array}$ \\
\hline Age-square & & & & & $\begin{array}{c}0.01 * \\
(0.003)\end{array}$ & $\begin{array}{l}0.005^{*} \\
(0.002)\end{array}$ \\
\hline Self support & & & & & & $\begin{array}{c}0.89^{* *} \\
(0.44)\end{array}$ \\
\hline Parental support & & & & & & $\begin{array}{c}0.81 \\
(0.52)\end{array}$ \\
\hline Spousal support & & & & & & $\begin{array}{c}0.46 \\
(0.51)\end{array}$ \\
\hline Constant & $\begin{array}{c}5.86^{* * *} \\
(0.78)\end{array}$ & $\begin{array}{c}5.81^{* * * *} \\
(0.78)\end{array}$ & $\begin{array}{c}5.508 * * * \\
(0.850)\end{array}$ & $\begin{array}{c}4.93 * * * \\
(1.04)\end{array}$ & $\begin{array}{c}12.48 * * * \\
(3.05)\end{array}$ & $\begin{array}{c}10.84 * * * \\
(3.43)\end{array}$ \\
\hline Number of observations & 107 & 107 & 107 & 107 & 107 & 107 \\
\hline Adjusted R-square & 0.06 & 0.05 & 0.6 & 0.06 & 0.11 & 0.14 \\
\hline
\end{tabular}

Robust standard errors are reported in parentheses.

$*$ significant at $10 \%$; * significant at $5 \%$; *** significant at $1 \%$ 
Table 4

OLS estimates of self allocation in a dictator game

\begin{tabular}{|c|c|c|c|c|c|c|}
\hline Variable & (1) & (2) & (3) & (4) & $(5)$ & (6) \\
\hline Years in university & $\begin{array}{c}0.0002 \\
(0.10)\end{array}$ & $\begin{array}{l}0.002 \\
(0.10)\end{array}$ & $\begin{array}{l}0.006 \\
(0.10)\end{array}$ & $\begin{array}{l}0.002 \\
(0.10)\end{array}$ & $\begin{array}{c}0.06 \\
(0.13)\end{array}$ & $\begin{array}{l}0.008 \\
(0.14)\end{array}$ \\
\hline Gender $($ female $=1)$ & $\begin{array}{l}-0.05 \\
(0.42)\end{array}$ & $\begin{array}{l}-0.01 \\
(0.42)\end{array}$ & $\begin{array}{c}-0.02 \\
(0.41)\end{array}$ & $\begin{array}{l}-0.017 \\
(0.41)\end{array}$ & $\begin{array}{l}-0.15 \\
(0.42)\end{array}$ & $\begin{array}{c}-0.04 \\
(0.43)\end{array}$ \\
\hline Policy students & $\begin{array}{l}-0.47 \\
(0.43)\end{array}$ & $\begin{array}{l}-0.43 \\
(0.42)\end{array}$ & $\begin{array}{l}-0.47 \\
(0.45)\end{array}$ & $\begin{array}{l}-0.48 \\
(0.46)\end{array}$ & $\begin{array}{c}0.14 \\
(0.65)\end{array}$ & $\begin{array}{c}0.36 \\
(0.64)\end{array}$ \\
\hline Economics courses & & $\begin{array}{c}0.072 * * \\
(0.03)\end{array}$ & $\begin{array}{c}0.07 * * \\
(0.03)\end{array}$ & $\begin{array}{c}0.07 * * \\
(0.03)\end{array}$ & $\begin{array}{c}0.08 * * * \\
(0.03)\end{array}$ & $\begin{array}{c}0.06^{* *} \\
(0.03)\end{array}$ \\
\hline Business students & & & $\begin{array}{c}0.16 \\
(0.48)\end{array}$ & $\begin{array}{c}0.15 \\
(0.48)\end{array}$ & $\begin{array}{c}0.02 \\
(0.50)\end{array}$ & $\begin{array}{c}0.19 \\
(0.48)\end{array}$ \\
\hline Total household income & & & & $\begin{array}{l}-0.01 \\
(0.17)\end{array}$ & $\begin{array}{c}-0.08 \\
(0.17)\end{array}$ & $\begin{array}{l}-0.05 \\
(0.16)\end{array}$ \\
\hline Age & & & & & $\begin{array}{l}-0.13 \\
(0.19)\end{array}$ & $\begin{array}{c}-0.009 \\
(0.21)\end{array}$ \\
\hline Age-square & & & & & $\begin{array}{c}0.001 \\
(0.003)\end{array}$ & $\begin{array}{r}-0.0003 \\
(0.003)\end{array}$ \\
\hline Self support & & & & & & $\begin{array}{c}-1.02 * * \\
(0.46)\end{array}$ \\
\hline Parental support & & & & & & $\begin{array}{c}0.32 \\
(0.57)\end{array}$ \\
\hline Spousal support & & & & & & $\begin{array}{c}-1.20 * \\
(0.65)\end{array}$ \\
\hline Constant & $\begin{array}{c}7.11 * * * \\
(0.59)\end{array}$ & $\begin{array}{c}6.73 * * * \\
(0.57)\end{array}$ & $\begin{array}{c}6.64 * * * \\
(0.61)\end{array}$ & $\begin{array}{c}6.68 * * * \\
(0.73)\end{array}$ & $\begin{array}{c}9.26 * * * \\
(3.00)\end{array}$ & $\begin{array}{c}7.76^{* *} \\
(3.22)\end{array}$ \\
\hline Number of observations & 107 & 107 & 107 & 107 & 107 & 107 \\
\hline R-squared & 0.01 & 0.06 & 0.06 & 0.06 & 0.09 & 0.15 \\
\hline
\end{tabular}

Robust standard errors are reported in parentheses.

$*$ significant at $10 \%$; * significant at $5 \%$; *** significant at $1 \%$ 
Table 5

Probit model of social votes in a multi-player tax game

\begin{tabular}{|c|c|c|c|c|c|c|}
\hline Variable & (1) & (2) & (3) & $(4)$ & (5) & (6) \\
\hline Status & $\begin{array}{c}0.015^{* * *} \\
(0.004)\end{array}$ & $\begin{array}{c}0.015^{* * *} \\
(0.004)\end{array}$ & $\begin{array}{c}0.015^{* * *} \\
(0.004)\end{array}$ & $\begin{array}{c}0.014 * * * \\
(0.004)\end{array}$ & $\begin{array}{c}0.013 * * * \\
(0.004)\end{array}$ & $\begin{array}{c}0.014 * * * \\
(0.009)\end{array}$ \\
\hline Self allocation in dictator game & $\begin{array}{c}-0.076^{* * *} \\
(0.021)\end{array}$ & $\begin{array}{c}-0.067 * * * \\
(0.022)\end{array}$ & $\begin{array}{c}-0.064 * * * \\
(0.022)\end{array}$ & $\begin{array}{c}-0.064 * * * \\
(0.022)\end{array}$ & $\begin{array}{c}-0.055^{* *} \\
(0.022)\end{array}$ & $\begin{array}{l}-0.040^{*} \\
(0.023)\end{array}$ \\
\hline Investment in risky asset & $\begin{array}{c}0.013 \\
(0.019)\end{array}$ & $\begin{array}{c}0.015 \\
(0.020)\end{array}$ & $\begin{array}{c}0.030 \\
(0.021)\end{array}$ & $\begin{array}{c}0.033 \\
(0.021)\end{array}$ & $\begin{array}{l}0.046^{*} \\
(0.022)\end{array}$ & $\begin{array}{c}0.032 \\
(0.022)\end{array}$ \\
\hline Sacrifice & $\begin{array}{l}-0.0002 \\
(0.005)\end{array}$ & $\begin{array}{l}-0.001 \\
(0.005)\end{array}$ & $\begin{array}{l}0.0001 \\
(0.006)\end{array}$ & $\begin{array}{l}0.0000 \\
(0.006)\end{array}$ & $\begin{array}{c}0.001 \\
(0.006)\end{array}$ & $\begin{array}{c}0.001 \\
(0.006)\end{array}$ \\
\hline Disadvantageous inequality & $\begin{array}{c}0.006 \\
(0.005)\end{array}$ & $\begin{array}{c}0.006 \\
(0.005)\end{array}$ & $\begin{array}{c}0.006 \\
(0.005)\end{array}$ & $\begin{array}{c}0.007 \\
(0.005)\end{array}$ & $\begin{array}{c}0.006 \\
(0.005)\end{array}$ & $\begin{array}{c}0.006 \\
(0.005)\end{array}$ \\
\hline Advantageous inequality & $\begin{array}{c}-0.023 * * * \\
(0.007)\end{array}$ & $\begin{array}{c}-0.024 * * * \\
(0.007)\end{array}$ & $\begin{array}{c}-0.025^{* * *} \\
(0.007)\end{array}$ & $\begin{array}{c}-0.024 * * * \\
(0.007)\end{array}$ & $\begin{array}{c}-0.025 * * * \\
(0.007)\end{array}$ & $\begin{array}{c}-0.025 * * * \\
(0.007)\end{array}$ \\
\hline Years in university & & $\begin{array}{c}-0.087 * * * \\
(0.026)\end{array}$ & $\begin{array}{c}-0.099 * * * \\
(0.027)\end{array}$ & $\begin{array}{c}-0.116^{* * *} \\
(0.028)\end{array}$ & $\begin{array}{c}-0.132 * * * \\
(0.031)\end{array}$ & $\begin{array}{c}-0.031 * * * \\
(0.0 .79)\end{array}$ \\
\hline Gender $($ female $=1)$ & & $\begin{array}{c}0.121 \\
(0.090)\end{array}$ & $\begin{array}{c}0.188^{* *} \\
(0.092)\end{array}$ & $\begin{array}{c}0.207^{* *} \\
(0.093)\end{array}$ & $\begin{array}{c}0.289 * * * \\
(0.098)\end{array}$ & $\begin{array}{c}0.301 * * * \\
(0.010)\end{array}$ \\
\hline Policy students & & $\begin{array}{c}0.271 * * * \\
(0.091)\end{array}$ & $\begin{array}{c}0.393 * * * \\
(0.096)\end{array}$ & $\begin{array}{c}0.374 * * * \\
(0.097)\end{array}$ & $\begin{array}{c}0.134 \\
(0.137)\end{array}$ & $\begin{array}{c}0.067 \\
(0.144)\end{array}$ \\
\hline Number of economics courses & & $\begin{array}{c}-0.004 \\
(0.007)\end{array}$ & $\begin{array}{c}0.007 \\
(0.007)\end{array}$ & $\begin{array}{l}-0.009 \\
(0.007)\end{array}$ & $\begin{array}{c}0.007 \\
(0.008)\end{array}$ & $\begin{array}{c}0.009 \\
(0.007)\end{array}$ \\
\hline Business students & & & $\begin{array}{c}-0.427^{* * *} \\
(0.094)\end{array}$ & $\begin{array}{c}-0.439^{* * *} \\
(0.094)\end{array}$ & $\begin{array}{c}-0.406^{* * *} \\
(0.095)\end{array}$ & $\begin{array}{c}-0.441 * * * \\
(0.097)\end{array}$ \\
\hline Total household income & & & & $\begin{array}{c}-0.071 * * \\
(0.036)\end{array}$ & $\begin{array}{c}-0.052 \\
(0.037)\end{array}$ & $\begin{array}{l}-0.066^{*} \\
(0.039)\end{array}$ \\
\hline Age & & & & & $\begin{array}{c}0.040 \\
(0.039)\end{array}$ & $\begin{array}{l}-0.029 \\
(0.043)\end{array}$ \\
\hline Age-squared & & & & & $\begin{array}{l}-0.0003 \\
(0.0005)\end{array}$ & $\begin{array}{l}-0.0002 \\
(0.001)\end{array}$ \\
\hline Self support & & & & & & $\begin{array}{c}0.289^{* * *} \\
(0.108)\end{array}$ \\
\hline Parental support & & & & & & $\begin{array}{c}0.062 \\
(0.130)\end{array}$ \\
\hline Spousal support & & & & & & $\begin{array}{c}0.128 \\
(0.159)\end{array}$ \\
\hline Constant & $\begin{array}{c}-0.924 * * * \\
(0.212)\end{array}$ & $\begin{array}{c}-0.678^{* * *} \\
(0.249)\end{array}$ & $\begin{array}{c}-0.569 * * \\
(0.251)\end{array}$ & $\begin{array}{l}-0.370 \\
(0.270)\end{array}$ & $\begin{array}{l}-1.311^{*} \\
(0.715)\end{array}$ & $\begin{array}{l}-1.364 \\
(0.766)\end{array}$ \\
\hline Number of observations & 1,391 & 1,391 & 1,391 & 1,391 & 1,391 & 1,391 \\
\hline Log likehood & -617.01 & -608.45 & -5979 & -0.596 .00 & -592.42 & -588.56 \\
\hline
\end{tabular}

Standard errors are reported in parentheses.

$*$ significant at $10 \%$; $* *$ significant at $5 \%$; *** significant at $1 \%$. 